\title{
Interplay between Fluid Extraction Mechanisms and Antigorite Dehydration Reactions (Val Malenco, Italian Alps)
}

\section{Maxime Clément, José Alberto Padrón-Navarta* and Andréa Tommasi}

Géosciences Montpellier, CNRS \& Université de Montpellier, Montpellier Cedex 5 F-34095, France

*Corresponding author. E-mail: padron@gm.univ-montp2.fr

\begin{abstract}
We investigate the feedback between antigorite dehydration reactions and fluid extraction mechanisms through the analysis of field-scale structures and microtextures formed by antigorite dehydration reactions producing olivine and talc in the Bergell intrusion contact aureole at Alpe Zocca (Malenco Unit, Northern Italy). The reactions, which resulted in the replacement of serpentinites by metaperidotites, occurred under quasi-static conditions. The main reaction front, which defines the equilibrium isograd, is an $\sim 150 \mathrm{~m}$ wide zone composed of variably reacted rocks with an irregular distribution at scales ranging from a few centimeters to a few meters. Veins composed of the prograde mineral assemblage occur downstream $(<100 \mathrm{~m})$ of this front. They are often surrounded by centimeter- to decimeter-scale dehydration reaction zones that propagate into the serpentinite wall-rock. Olivine in the metaperidotites and partially reacted serpentinites has a crystallographic preferred orientation (CPO) correlated with the antigorite CPO, with $[010]_{O I}$ axes parallel to $[001]_{A t g}$. This CPO is accompanied by a shape-preferred orientation (SPO) that marks the foliation in both rock types. Olivine crystals in OI-TIc dehydration veins also have SPO and CPO that define a jackstraw texture within the plane of the vein. They are elongated parallel to [001] within the vein plane and have their $[010]_{\mathrm{O}}$ axes normal to the vein. We interpret the olivine-talc assemblage in the veins as resulting from dehydration reactions at lower temperature than the equilibrium conditions owing to fluid extraction from the wall-rock into the veins. The jackstraw texture indicates fast kinetics, with the crystal orientation controlled by anisotropic growth under a fluid pressure gradient. We interpret the foliated metaperidotites as formed at near equilibrium conditions, with pervasive fluid extraction from the metaperidotite by viscous metamorphic compaction. Olivine CPO in these rocks may result from topotaxy, oriented growth in the presence of an anisotropic (foliation-controlled) fluid flow, and/or solid reorientation of the anisometric olivine crystals accommodated by the deformation of the weaker talc ( \pm chlorite) matrix during compaction.
\end{abstract}

Key words: serpentinite; dehydration reactions; fluid migration; microstructures; crystal preferred orientations; effective pressure; fluid pressure; compaction

\section{INTRODUCTION}

Dehydration reactions produce a significant net decrease of the solid volume as well as a large volume of fluids, resulting in a fluid-filled porosity. The low permeability of crystalline rocks surrounding dehydration fronts at middle crust and greater depths (e.g. Manning \& Ingebritsen, 1999) should prevent efficient large-scale pervasive fluid migration through an interconnected pore network (e.g. Leclère et al., 2018). In the absence of fluid extraction, increase in fluid pressure decreases the effective pressure (difference between the confining pressure and the fluid pressure) and, by consequence, slows down the reaction rates (e.g. Llana-Fúñez et al., 2007, 2012). Successful models of pervasive fluid flow during replacement reactions in the crust and mantle require metastability of the solid matrix in contact with 
the percolation aqueous fluid (i.e. coupled dissolutionprecipitation driven by chemical fluid-rock disequilibrium interaction; Putnis, 2002; Putnis \& Putnis, 2007; Putnis \& John, 2010; Etschmann et al., 2014; Plümper et al., 2017 b). In such situations, it has been shown that chemical potential gradients along the fluid-filled nanoporosity (diffusio-osmosis) and those related to electrical charges (electro-osmosis) may be as important as fluid pressure gradients in controlling fluid flux (Kar et al., 2016; Plümper et al., 2017a). However, aqueous fluids released by a homogeneous lithological column being dehydrated are not expected to be significantly far from equilibrium when brought in contact with the surrounding unreacted protolith. Furthermore, dehydration reactions have the potential to produce a significant volume of fluid-filled porosity over discrete temperature ranges (i.e. discontinuous dehydration reactions) and, hence, fluid-filled pore spaces well beyond nanoporosity (Bedford et al., 2017). Dissolution-precipitation alone is therefore not an efficient mechanism for fluid extraction during dehydration reactions.

Alternative models for fluid migration during dehydration reactions rely on the deformation of the solid matrix or on a hierarchical channelling of an initially heterogeneous distribution of fluid-pockets (Miller et al., 2003; Plümper et al., 2017b). Under the high-pressure and high-temperature conditions prevailing in the middle and lower crust and mantle, viscous compaction has been proposed as an efficient draining mechanism (Connolly, 1997, 2010). When the time scale for viscous compaction is shorter than the time scale of fluid production, fluid migration takes place through porosity waves that propagate independently of the reaction front (Connolly, 1997, 2010; Connolly \& Podladchikov, 1998, 2013, 2015). Alternatively, if the time scale for compaction is larger (cooler and lower pressure conditions), the rocks remain rigid on the time scale of the reaction and fluid overpressure may result in fracturing. The widespread occurrence of synmetamorphic veins in the upper crust (e.g. Etheridge et al., 1983) is usually taken as evidence for the latter process (Nakashima, 1995; Flekkøy et al., 2002; Okamoto et al., 2017).

Numerical models dealing with fluid migration by porosity waves and/or hydrofracturing are increasingly more sophisticated (e.g. Flekkøy et al., 2002; Malvoisin et al., 2015), but experimental and natural observations constraining the contribution of these two processes in different geological settings remain elusive. Yet they should result in contrasting magnitudes of the difference between the transient fluid pressure and the confining pressure, which in turn should affect the reaction rates (Llana-Fúñez et al., 2007, 2012). Viscous compaction should be associated with low effective pressure (fluid pressure approaches lithostatic pressure), whereas hydrofracturing is the result of a transient overpressure (fluid pressure higher than lithostatic) that rapidly evolves towards high effective pressure owing to an increase in permeability coeval with crack propagation and connection to external reservoirs. Because effective pressure influences reaction kinetics and, by consequence, grain growth processes (Lasaga, 1989; Miller et al., 2003; Wang \& Wong, 2003; Hildyard et al., 2011; Llana-Fúnez et al., 2012; Leclère et al., 2018), the microstructural investigation of dehydrated rocks (PadrónNavarta et al., 2010b, 2011, 2015; Clément et al., 2018; Dilissen et al., 2018) is an appealing tool to deduce the fluid migration mechanisms active in nature.

The purpose of this work is to investigate the mechanisms of fluid migration during antigorite dehydration by studying macro- and microstructures over a $1 \mathrm{~km}^{2}$ exposure of partially dehydrated antigorite-schist in the Malenco unit (Northern Italy). Serpentinites from this locality were dehydrated under quasi-static conditions in response to the intrusion of the Bergell tonalite (Evans \& Trommsdorff, 1970, 1974a; Trommsdorff \& Evans, 1972, 1974, 1977, 1980; Montrasio \& Trommsdorff, 1983; Trommsdorff \& Nievergel, 1983; Mellini et al., 1987; Worden et al., 1991; Trommsdorff et al., 2000, 2005). They offer therefore a unique opportunity to follow an undisturbed sequence of antigorite (Pfeifer et al., 1993) dehydration reactions at the kilometer scale and track the mechanisms of fluid extraction during these reactions.

\section{GEOLOGICAL SETTING}

The Malenco unit is located at the transition between the lower Austroalpine Margna and the upper Penninic Suretta nappes (Fig. 1a; Trommsdorff \& Evans, 1972; Peretti et al., 1992; Müntener \& Hermann, 1996; Hermann et al., 1997; Trommsdorff et al., 2005). It comprises a fossil lower crust-upper mantle section mainly composed of gabbros, peridotites, serpentinites, ophicarbonates, and lower crust high-grade metapelites (Müntener \& Hermann, 1996; Hermann et al., 1997). The ultramafic rocks from the Malenco unit are interpreted as part of the Adriatic subcontinental lithosphere exhumed by rifting in the Jurassic up to exposure at the seafloor of the Piemont Ligurian Ocean (see the dashed grey pressure-temperature path in Fig. 1b from Hermann, 1997; Müntener, 1997; Müntener et al., 1999). During exhumation and exposure at the ocean floor, the ultramafic rocks were serpentinized and ophicarbonates were formed in them, both within fractures and as platform sediments (Trommsdorff \& Evans, 1977).

The assemblage of ultramafic rocks, mafic rocks, and ophicarbonates was subducted to moderate depths in the late Cretaceous to early Tertiary, as recorded by regional Alpine metamorphism at greenschist- to epidoteamphibolite-facies conditions (Fig. 1b, peak temperature and pressure estimated at $450^{\circ} \mathrm{C}$ and $5.5 \mathrm{kbar}$; see Hermann, 1997; Hermann et al., 1997; Müntener, 1997; Trommsdorff et al., 2000). This subduction-related metamorphism led to transformation of the chrysotilebearing serpentinized peridotites to antigorite-schists with a mineral assemblage of Atg $+\mathrm{Ol}+\mathrm{Di}+\mathrm{Chl}+$ Mag (abbreviations as given by Whitney \& Evans, 2010) with Ti-clinohumite, brucite, and sulfides as accessory phases (Trommsdorff \& Evans, 1974; Mellini et al., 



Fig. 1. (a) Geological setting of the Malenco Unit, Italian Alps (after Trommsdorff \& Evans, 1974). Labelled lines $P$, B and OL are isograds for non-ultramafic lithologies $(P$, pumpellyite-out, coincident with the chrysotile/lizardite to antigorite reaction; $B$, biotite-in; $\mathrm{OL}$, oligoclase-in) and numbers 1-4 are isograds for ultramafic lithologies (see text). Isograds $1 \mathrm{a}$ and $1 \mathrm{~b}$ are from Peretti et al., (1992), where indentation indicates the side at which olivine is stable. Ultramafic rocks include peridotites and serpentinites. The studied area (Alpe Zocca) is indicated by a small black rectangle and is shown enlarged in (c). (b) A representative pseudosection in the $\mathrm{CaO}-\mathrm{FeO}-\mathrm{MgO}-\mathrm{Al}_{2} \mathrm{O}_{3}-\mathrm{SiO}_{2}-\mathrm{H}_{2} \mathrm{O}$ system (fluid-saturated), showing isograds $1 \mathrm{a}$ and $1 \mathrm{~b}$ related to the Cretaceous convergence (Alpine metamorphism) and isograds related to the contact metamorphism of the Bergell intrusion (Trommsdorff et al., 2000, and references therein). The reaction lizardite to antigorite and brucite is from Evans (2004). Also shown, as a dashed grey $P-T$ path, is the pre-Alpine retrograde metamorphism. It should be noted that isograd 4 is not well defined, as anthophyllite occurs only sporadically in veins. CdA corresponds to the peak metamorphic conditions of Cerro del Almirez (Spain) discussed in the text. (c) Map of the studied area (from Trommsdorff et al., 2005, with slight modifications) indicating the position of the contact metamorphism isograds 2 and 3 (the latter corresponds to an $\sim 150 \mathrm{~m}$ wide zone composed of variably reacted rocks with an irregular distribution at scales ranging from a few centimeters to a few meters), the studied dehydration veins, and sampling locations. The black line marks the profile along which the crystal preferred orientation (CPO) data presented in Figs 10, 11 and 13 a have been projected. 
1987; Worden et al., 1991; Peretti, 1988; Peretti et al., 1992; Trommsdorff \& Connolly, 1996). Olivine in this assemblage results from two possible reactions (in the simplified $\mathrm{MgO}-\mathrm{SiO}_{2}-\mathrm{H}_{2} \mathrm{O}$ system):

$$
\begin{aligned}
& 20 \mathrm{Mg}_{3} \mathrm{Si}_{2} \mathrm{O}_{5}(\mathrm{OH})_{4}=\underset{\text { chrysotile }}{\mathrm{Mg}_{48} \mathrm{Si}_{34} \mathrm{O}_{85}(\mathrm{OH})_{62}} \\
& +6 \underset{\text { forsterite }}{\mathrm{Mg}_{2} \mathrm{SiO}_{4}}+\underset{\text { aqueous fluid }}{9 \mathrm{H}_{2} \mathrm{O}} \\
& \mathrm{Mg}_{48} \mathrm{Si}_{34} \mathrm{O}_{85}(\mathrm{OH})_{62}+20 \mathrm{Mg}(\mathrm{OH})_{2} \\
& \text { antigorite brucite } \\
& =34 \mathrm{Mg}_{2} \mathrm{SiO}_{4}+51 \mathrm{H}_{2} \mathrm{O}
\end{aligned}
$$

These two reactions have been mapped in the north and easternmost part of the Malenco ultramafic unit (Fig. 1a) by Peretti (1988) and Peretti et al. (1992)). Before the Bergell intrusion, a large part of the Malenco unit was therefore at upper greenschist-facies conditions, where olivine and antigorite coexist in equilibrium (Fig. 1b).

High-grade contact metamorphism triggered by the composite Bergell intrusion at $32 \mathrm{Ma}$ (Von Blanckenburg et al., 1992) locally overprinted the regional metamorphism, producing a contact aureole $c$. $1-1.5 \mathrm{~km}$ wide in the ultramafic rocks of the Malenco unit. This intrusion occurred after the main episode of Alpine thrusting and folding (Trommsdorff \& Evans, 1977; Trommsdorff et al., 2005). The southernmost part of the Malenco unit and the Bergell intrusion are deformed in the Insubric Line, but no major Cenozoic deformation affects the study area. Trommsdorff \& Evans (1972) mapped two isograds associated with the contact metamorphism in the $\mathrm{CaO}-\mathrm{MgO}-\mathrm{SiO}_{2}-\mathrm{H}_{2} \mathrm{O}$ ( $\mathrm{CMSH}$ ) system, corresponding to the following reactions (Fig. 1a and b):

$$
\begin{aligned}
& \mathrm{Mg}_{48} \mathrm{Si}_{34} \mathrm{O}_{85}(\mathrm{OH})_{62}+2 \underset{\text { antigorite }}{\mathrm{CaMgSi}_{2}} \mathrm{O}_{6} \\
& =2 \mathrm{Ca}_{2} \mathrm{Mg}_{\text {tremolite }}^{\mathrm{Si}_{8} \mathrm{O}_{22}}(\mathrm{OH})_{2}+\underset{\text { olivine }}{21} \mathrm{Mg}_{2} \mathrm{SiO}_{4}+\underset{\text { aqueous fluid }}{28 \mathrm{H}_{2} \mathrm{O}} \\
& 5 \mathrm{Mg}_{48} \mathrm{Si}_{\text {antigorite }} \mathrm{O}_{85}(\mathrm{OH})_{62}=\underset{\text { olivine }}{\mathrm{Mg}_{2} \mathrm{SiO}_{4}}+\underset{\text { talc }}{\mathrm{Mg}_{3}} \mathrm{Si}_{4} \mathrm{O}_{10}(\mathrm{OH})_{2} \\
& +27 \mathrm{H}_{2} \mathrm{O} \text {. }
\end{aligned}
$$

The conditions of reaction (2) also correspond to the decomposition of titano-clinohumite to olivine + ilmenite $+\mathrm{H}_{2} \mathrm{O}$. Trommsdorff \& Evans (1972) interpreted the contact between ultramafic and intrusive rocks as roughly vertical, with isograds parallel to the intrusion (Fig. 1a). This contrasts with the isograd of reactions (1a) and (1b), related to the previous regional Alpine metamorphism, which is roughly horizontal (Fig. 1a; Peretti, 1988; Peretti et al., 1992). Trommsdorff \& Connolly (1996) estimated a pressure of $3.5 \mathrm{kbar}$ for the contact metamorphism around the Bergell aureole, with an upper limit of $4 \mathrm{kbar}$ based on phase relations in the ophicarbonates (Connolly \& Trommsdorff, 1991). Mineral assemblages containing anthophyllite and enstatite associated with reactions (4) and (5), respectively, occur sporadically within $100 \mathrm{~m}$ from the intrusion (Trommsdorff \& Evans, 1972), thus making it difficult to trace the isograds (Trommsdorff \& Connolly, 1996). They were not investigated in the present study.

$$
\begin{gathered}
2 \mathrm{Mg}_{3} \mathrm{Si}_{4} \mathrm{O}_{10}(\mathrm{OH})_{2}+\mathrm{Mg}_{2} \mathrm{SiO}_{4} \\
=\underset{\text { olivine }}{\mathrm{Mg}_{7} \mathrm{Si}_{8} \mathrm{O}_{22}(\mathrm{OH})_{2}}+\underset{\text { aqueous fluid }}{\mathrm{H}_{2} \mathrm{O}}
\end{gathered}
$$

$\underset{\text { anthophyllite }}{\mathrm{Mg}_{7} \mathrm{Si}_{8} \mathrm{O}_{22}(\mathrm{OH})_{2}}+\underset{\text { olivine }}{\mathrm{Mg}_{2} \mathrm{SiO}_{4}}=9 / 2 \underset{\text { enstatite }}{\mathrm{Mg}_{2} \mathrm{Si}_{2} \mathrm{O}_{6}}+\underset{\text { aqueous fluid }}{\mathrm{H}_{2} \mathrm{O}}$

Figure $1 \mathrm{~b}$ shows a temperature-pressure phase diagram (pseudosection) in the $\mathrm{CaO}-\mathrm{FeO}-\mathrm{MgO}-\mathrm{Al}_{2} \mathrm{O}_{3}-$ $\mathrm{SiO}_{2}-\mathrm{H}_{2} \mathrm{O}$ (CFMASH) system for a Ca-poor antigorite serpentinite whole-rock composition (sample MA16-51A, a serpentinite hosting an OI-Tlc vein, only the serpentinite wall-rock composition is used in the calculation; Table 1). The phase diagram was computed using Perple_X (6.8.6, Connolly, 2009), the thermodynamic database of Holland \& Powell (2011), the compensated-Redlich-Kwong (CORK) equation of state for the fluid and the solid solution models used by Padrón-Navarta et al. (2013; see their Table 1). The ferric iron is at present difficult to model because of the lack of a solid solution model accounting for $\mathrm{Fe}^{3+}$ in antigorite, therefore the effective bulk rock was recast by subtracting $3 \mathrm{wt} \%$ of magnetite (e.g. López Sánchez-Vizcaíno et al., 2005). Chlorite is an additional product phase of some of the reactions listed above owing to the solubility of aluminium in the reactant antigorite through a Tschermak's exchange (e.g. Padrón-Navarta et al., 2013). Figure 1b also shows the high-pressure antigorite-out reaction, so far only reported in Cerro del Almirez, Spain (Trommsdorff et al., 1998; Padrón-Navarta et al., 2011):

$$
\begin{aligned}
\mathrm{Mg}_{48} \mathrm{Si}_{34} \mathrm{O}_{85}(\mathrm{OH})_{62}= & 14 \underset{\text { antigorite }}{\mathrm{Mg}_{2} \mathrm{SiO}_{4}}+20 \underset{\text { enstatite }}{\mathrm{Mg}_{2} \mathrm{Si}_{2} \mathrm{O}_{6}} \\
& +\underset{\text { aqueous fluid }}{31 \mathrm{H}_{2} \mathrm{O}}
\end{aligned}
$$

\section{METHODS}

Detailed sampling and structural mapping of a $1 \mathrm{~km} \times 1 \mathrm{~km}$ area was undertaken in the northeastern part of the contact aureole of the Bergell intrusion, along the western side of the Val Ventina (Alpe Zocca, Northern Italy, Fig. 1a and c) to investigate the evolution of antigorite schists to olivine-talc (OI-Tlc) metaperidotites and, in Ca-rich domains, of diopside-bearing antigorite schists to tremolite-bearing antigorite schists through reactions (2) and (3). Foliation planes (and when possible lineations) of serpentinites and metaperidotite were measured to map possible structural 
Table 1: Representative whole-rock compositions and modal mineralogy of different types of ultramafic rocks in Alpe Zocca (Malenco unit)

\begin{tabular}{|c|c|c|c|c|c|c|c|c|}
\hline $\begin{array}{l}\text { Type: } \\
\text { Sample: }\end{array}$ & $\begin{array}{l}\text { S } \\
\text { MA16-17 }\end{array}$ & $\begin{array}{l}S^{*} \\
\text { MA16-51A }\end{array}$ & $\begin{array}{l}\text { Tr-S } \\
\text { MA16-36 }\end{array}$ & $\begin{array}{l}\text { S-r } \\
\text { MA16-42 }\end{array}$ & $\begin{array}{l}\text { Vein } \\
\text { MA16-51C }\end{array}$ & $\begin{array}{l}\text { M } \\
\text { MA17-34 }\end{array}$ & $\begin{array}{l}\text { M } \\
\text { MA16-48 }\end{array}$ & $\begin{array}{l}\text { Js } \\
\text { MA16-12A }\end{array}$ \\
\hline \multicolumn{9}{|c|}{ Major elements determined by XRF (wt \%) } \\
\hline $\mathrm{SiO}_{2}$ & 42.02 & 41.66 & 45.97 & 45.94 & 44.23 & $46 \cdot 24$ & $42 \cdot 36$ & 43.59 \\
\hline $\mathrm{TiO}_{2}$ & 0.01 & 0.01 & 0.01 & 0.01 & 0.01 & 0.01 & 0.01 & 0.01 \\
\hline $\mathrm{Al}_{2} \mathrm{O}_{3}$ & 0.99 & 1.82 & 1.02 & 2.20 & 1.35 & 1.15 & 1.39 & 0.79 \\
\hline $\mathrm{Cr}_{2} \mathrm{O}_{3}$ & 0.36 & 0.41 & 0.43 & 0.39 & 0.35 & 0.47 & 0.53 & 0.52 \\
\hline $\mathrm{Fe}_{2} \mathrm{O}_{3}^{\dagger}$ & 2.53 & 3.59 & $4 \cdot 16$ & 0.87 & $2 \cdot 61$ & 3.08 & 4.97 & $2 \cdot 16$ \\
\hline $\mathrm{FeO}$ & 4.46 & $2 \cdot 38$ & 2.54 & $4 \cdot 20$ & 4.48 & 3.90 & $5 \cdot 25$ & $7 \cdot 12$ \\
\hline $\mathrm{NiO}$ & 0.20 & 0.20 & 0.27 & 0.21 & 0.20 & 0.29 & 0.31 & 0.26 \\
\hline $\mathrm{MnO}$ & 0.09 & 0.08 & 0.10 & 0.09 & 0.17 & 0.09 & 0.14 & 0.23 \\
\hline $\mathrm{MgO}$ & 37.55 & $38 \cdot 32$ & 34.76 & 37.54 & 39.15 & 39.79 & 41.57 & 41.31 \\
\hline $\mathrm{CaO}$ & 0.01 & 0.08 & $5 \cdot 12$ & 0.50 & $2 \cdot 16$ & 0.24 & 0.08 & 0.61 \\
\hline $\mathrm{Na}_{2} \mathrm{O}$ & 0.01 & 0.00 & 0.02 & 0.02 & 0.02 & $<0.01$ & $<0.01$ & $<0.01$ \\
\hline LOI & 11.20 & $11 \cdot 10$ & $5 \cdot 30$ & 8.04 & 4.70 & 4.30 & 2.70 & 2.60 \\
\hline Total & 99.42 & 99.65 & $99 \cdot 70$ & 99.79 & 99.41 & 99.55 & 99.31 & $99 \cdot 19$ \\
\hline \multicolumn{9}{|c|}{ Mode (mass-balance wt \%) } \\
\hline Antigorite & 98 & 94 & 19 & 51 & - & - & 1 & 1 \\
\hline Olivine & - & 2 & 29 & 20 & 39 & 47 & 68 & 70 \\
\hline Tremolite & - & 1 & 38 & 4 & 10 & 6 & - & - \\
\hline Chlorite & - & - & 10 & 8 & 1 & 1 & 7 & - \\
\hline Talc & - & - & - & 16 & 47 & 44 & 20 & 27 \\
\hline Magnetite & 2 & 3 & 4 & 1 & 3 & 2 & 4 & 1 \\
\hline
\end{tabular}

* Serpentinite wall rock of the the Ol-Tlc vein MA16-51C.

${ }^{\dagger}$ Ferric iron was calculated from the difference of the total iron measured by XRF and the measured ferrous iron.

Types: S, Atg-serpentinite; Tr-S, tremolite-bearing serpentinite; S-r, partially reacted serpentinite; M, pervasive metaperidotite; Js, jackstraw-textured OI-TIc vein. LOI, loss on ignition.

continuity between the different lithologies. We also documented the orientations of olivine-bearing veins that are locally conspicuous (Figs 1c and 2). Care was taken during structural measurements to avoid errors owing to the high proportion of magnetite in the ultramafic lithologies in this locality (see Shive et al., 1988).

Blocks of $\sim 500 \mathrm{~g}$ were cut from representative samples for bulk-rock chemical analyses, avoiding all altered parts. The samples were crushed in an agate mortar to an $\sim 80 \mu \mathrm{m}$ grain size powder. Approximately $50 \mathrm{~g}$ were used for analyses. Whole-rock major and minor element analysis was performed at Bureau Veritas Mineral Laboratory, Vancouver (Canada), using lithium borate fusion coupled to inductively coupled plasma emission spectrometry (ICP-ES). Additional analyses were conducted on selected samples to quantify $\mathrm{FeO}$ content (and $\mathrm{Fe}_{2} \mathrm{O}_{3}$ by difference) by the titration technique.

Petrographic analyses were carried out by optical microscopy to investigate microstructural relationships between antigorite and its dehydration products and the presence or not of viscoplastic deformation of the dehydration products. For geographically oriented samples, thin sections were prepared from sections oriented parallel to the vertical east-west plane looking from the south (i.e. the south direction points upward from the thin section surface and the long axis of the thin section is parallel to the east-west vertical plane). This orientation was chosen because the foliation predominantly dips towards the east in the study area. Non-oriented samples were prepared normal to the foliation plane, when visible. A few additional thin sections were prepared parallel to the foliation plane. All thin sections were polished with diamond paste, followed by colloidal silica for $4 \mathrm{~h}$, and by a last stage of chemical polishing with colloidal silica in a vibratory polisher machine (VibroMet ${ }^{\mathrm{TM}}$ ) for another $4 \mathrm{~h}$. Despite this procedure, diffraction patterns were seldom acquired for talc owing to its contrasting polishing properties relative to the other silicates, hindering the measurement of its crystal orientations.

Crystal preferred orientations of antigorite, olivine, tremolite, as well as diopside and magnetite, when present, were measured by electron-backscattered diffraction (EBSD) at Géosciences Montpellier (France). A JEOL 5600 scanning electron microscope equipped with a NordlysNano EBSD detector was used to map the orientation of all major rock-forming phases with a resolution of $16-27 \mu \mathrm{m}$ over whole thin sections. A Camscan Crystal Probe XF500 with a NordlysNano EBSD detector was used to measure orientations of antigorite and olivine over smaller areas with a higher spatial resolution $(8 \mu \mathrm{m})$. Binning mode was set to $4 \times 4$ and accelerating voltage to $17 \mathrm{kV}$. To enhance antigorite indexation rates, we used two crystal structures for indexation [corresponding to polysomes $m=16$ and $m=17$; Capitani \& Mellini (2006) and (2004), respectively] and merged the two orientation datasets for data treatment. Because thin sections were prepared at a high angle to the foliation plane, potential misindexation is expected for the [100] and [010] axes of antigorite (Padrón-Navarta et al., 2012; Nagaya et al., 2014). The orientation of the [001] axes of antigorite is, nevertheless, well constrained and, as expected, normal to the foliation measured in the field. 
Orientation data were expressed as Bunge Euler angles and processed with the MATLAB toolbox MTEX (Hielscher \& Schaeben, 2008; Bachmann et al., 2010; Mainprice et al., 2014). Grain detection was performed with a mis-orientation threshold of $15^{\circ}$. Grains composed by $<3$ pixels were removed from the dataset. Orientation distribution functions for all phases were calculated using a 'de la Vallée Poussin' kernel with a constant half-width of $10^{\circ}$. Pole figures of antigorite and olivine were plotted in the lower hemisphere using the grain average orientation and a constant colour bar (0-4 multiples of a uniform distribution, m.u.d.) for easy comparison between samples. The intensity of the crystal preferred orientation (CPO) is characterized by the $J$ index (Bunge, 1982). The symmetry of the olivine CPO is characterized in terms of symmetry of the orientation distribution of the [010] and [001] axes by the BC-index. This index is calculated similarly to the BA-index (Mainprice et al., 2014) according to the following expression:

$$
\mathrm{BC} \text { index }=\frac{1}{2}\left[2-\left(\frac{P_{010}}{P_{010}+G_{010}}\right)-\left(\frac{G_{001}}{G_{001}+P_{001}}\right)\right]
$$

where $P$ and $G$ are the point and girdle indices of Vollmer (1990), respectively. If the [010] axes of olivine define a perfect point concentration and the [001] axes form a girdle, the BC-index value is zero. If the [001] axes of olivine define a point concentration and the [010] axes form a girdle, the BC-index value is unity. CPOs with orthorhombic symmetry (point concentrations of both [010] and [001] axes) are characterized by $\mathrm{BC}$-index values of 0.5 .

\section{FIELD OBSERVATIONS}

\section{Serpentinites and pervasive metaperidotites}

Within the study area, from east to west, serpentinites evolve to fully reacted metaperidotites (Fig. 1c). The two isograds corresponding to reactions (2) and (3) crop out at c. $1230 \mathrm{~m}$ and at $c .770 \mathrm{~m}$ from the intrusion, respectively. The observed distance of the two isograds from the contact with the Bergell intrusion is consistent with the predictions by the numerical model of Trommsdorff \& Connolly (1996): 1110-1310m and 500$710 \mathrm{~m}$, respectively.

The serpentinite is a greenish schistose fine-grained rock composed of antigorite with variable amounts of olivine, diopside, tremolite, magnetite, and chlorite (Trommsdorff \& Evans 1972). The intensity of the schistosity varies spatially. Massive serpentinite with poorly defined foliation is not uncommon, but in most of the studied area a foliation could be measured in the field (Fig. 2). This foliation is marked by the shape-preferred orientation (SPO) of antigorite (Fig. 3a). Locally, magnetite forms elongated aggregates marking a lineation in the foliation plane. Metamorphic olivine appears as red-orange (on altered surfaces) or dark millimeter- to centimeter-scale crystals with rounded or prismatic shapes. In addition to olivine, serpentinites may contain metamorphic diopside, which typically occurs as white millimeter-scale prismatic crystals, or tremolite, which occurs as white acicular millimeter-scale crystals (Fig. 3a) replacing metamorphic diopside close to the contact with the pluton. The presence of diopside and tremolite indicates a locally more fertile (Iherzolitic, Carich) protolith. Spatial distribution of $\mathrm{Ca}$-free and $\mathrm{Ca}$ rich serpentinites does not show any regular arrangement. This observation is confirmed by larger scale mapping of the Malenco serpentinites (Lafay et al., 2019). Serpentinites with relict mantle clinopyroxene, which occurs as dark green millimeter-scale crystals [referred to as 'dusty' diallage or clinopyroxene by Trommsdorff \& Evans (1972)], are common on the eastern side of the valley (Lago Pirola) and restricted to the eastern side of isograd 2 in our study area.

The strike of the serpentinite foliation gradually rotates from a NNW orientation steeply dipping $\left(\sim 80^{\circ}\right)$ towards the ENE close to the isograd of reaction (2) to a more NNE strike orientation when approaching the isograd of reaction (3) (Fig. 2). Locally, foliations with opposite dip directions are observed; they are associated with mesoscale open folds or crenulations. The dip of the foliation plane in the serpentinites is opposite to the one determined by Hermann \& Muntener (1996) on the eastern side of the Val Ventina valley (inset in Fig. 2), constraining the axis of a kilometer-scale fold (NNE subhorizontal, subparallel to the trend of the Val Ventina; Trommsdorff et al., 2005). Lineations marked by the elongation of magnetite aggregates in serpentinites show variable dip (Fig. 2), in contrast to the lineations reported by Hermann \& Muntener (1996) on the eastern side of the valley, which are dominantly NW subhorizontal.

The serpentinites are progressively transformed to olivine-talc ( \pm tremolite \pm chlorite) metaperidotites through reaction (3) (Fig. $1 \mathrm{~b}$ and c). Ol-Tlc ( $\pm \operatorname{Tr} \pm$ Chl) rocks are less schistose and more massive than antigorite schists, but a weak foliation can still be recognized in the field. The transition between serpentinites and metaperidotites is smooth. It occurs over a c. $150 \mathrm{~m}$ wide domain (indicated by the colour gradient in Fig. 1c), composed of partially dehydrated rocks characterized by layers, patches, or irregularly shaped septa of Ol-Tlc ( $\pm \mathrm{Tr} \pm \mathrm{Chl}$ ) rocks intercalated with serpentinites (Fig. 3b).

Metaperidotites are defined by the presence of more than 90 vol. \% of product phases from dehydration reaction (3): Ol-Tlc ( $\pm \operatorname{Tr} \pm$ Chl). They appear as dark grey roughly foliated rocks in fresh surfaces, but have reddish to whitish tones on altered surfaces (Fig. 3c and d). Fine-grained metaperidotites (with submillimetric olivine) predominate. These rocks often show a rough compositional layering marked by alternating Ol-rich and Tlc-rich domains (Fig. 3c). They may display a foliation owing to the shape-preferred orientation (SPO) of olivine and a lineation marked by the alignment of magnetite aggregates (Fig. 3c). Locally, metaperidotites are 


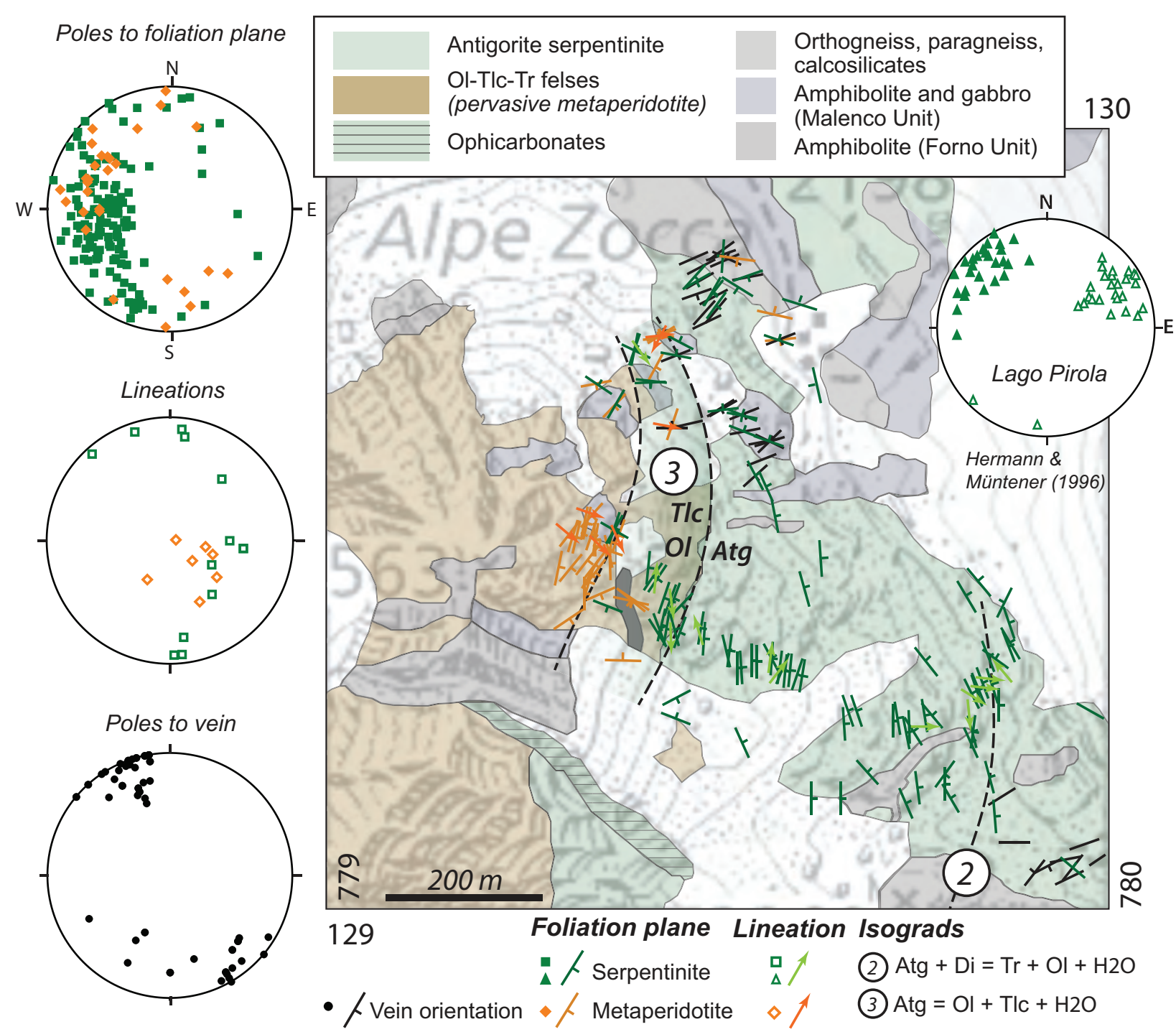

Fig. 2. Orientations of foliations and lineations in the serpentinites (green symbols) and metaperidotites (orange symbols) in the studied area. Dehydration veins are plotted in black. Lower hemisphere stereographic projections in the geographical reference frame on the left summarize, from top to bottom, all foliation, lineation, and vein structural data acquired in the studied area. Inset at top right shows previous measurements of foliation and lineation of ultramafic rocks from the other (eastern) side of Val Ventina (Hermann \& Muntener, 1996).

coarse-grained containing centimeter-scale olivine crystals associated with white talc flakes and dark grey chlorite crystals (Fig. 3d). Coarse-grained metaperidotites are usually foliated. No clear spatial arrangement between fine-grained and coarse-grained metaperidotite as a function of the distance from the Bergell intrusion was observed within the study area. This observation contrasts with the increase in grain size with increasing distance from the Bergell intrusion proposed by Lafay et al. (2019) based on larger scale mapping of the Malenco serpentinites. The strike of the metaperidotite foliation is remarkably similar to that of the serpentinites close to the OI-Tlc isograd (Fig. 2). The lineation tends, however, to have steeper plunges in the metaperidotites than in serpentinites (Fig. 2).

\section{Metamorphic (dehydration) veins}

A striking feature of the study area (Alpe Zocca) is the common occurrence of olivine-bearing veins with variable sizes and shapes (Trommsdorff \& Evans, 1974; Trommsdorff \& Connolly, 1996). Two types of olivinebearing veins have been identified: $\mathrm{Ol}-( \pm T r)$ veins and Ol-Tlc veins, which are concentrated just before (downstream of) the isograds of reactions (2) and (3), respectively (Figs 1c and 2). The veins are dominantly oriented $\mathrm{N} 60-70^{\circ}$ with a subvertical dip; they most often crosscut the serpentinite foliation (Fig. 2).

The most distant veins from the intrusion are Ol$( \pm T r$ ) veins (Figs $1 \mathrm{c}$ and $4 \mathrm{a})$. These veins are centimeters to decimeters wide and may usually be followed for a few meters. They contain olivine and occasionally 

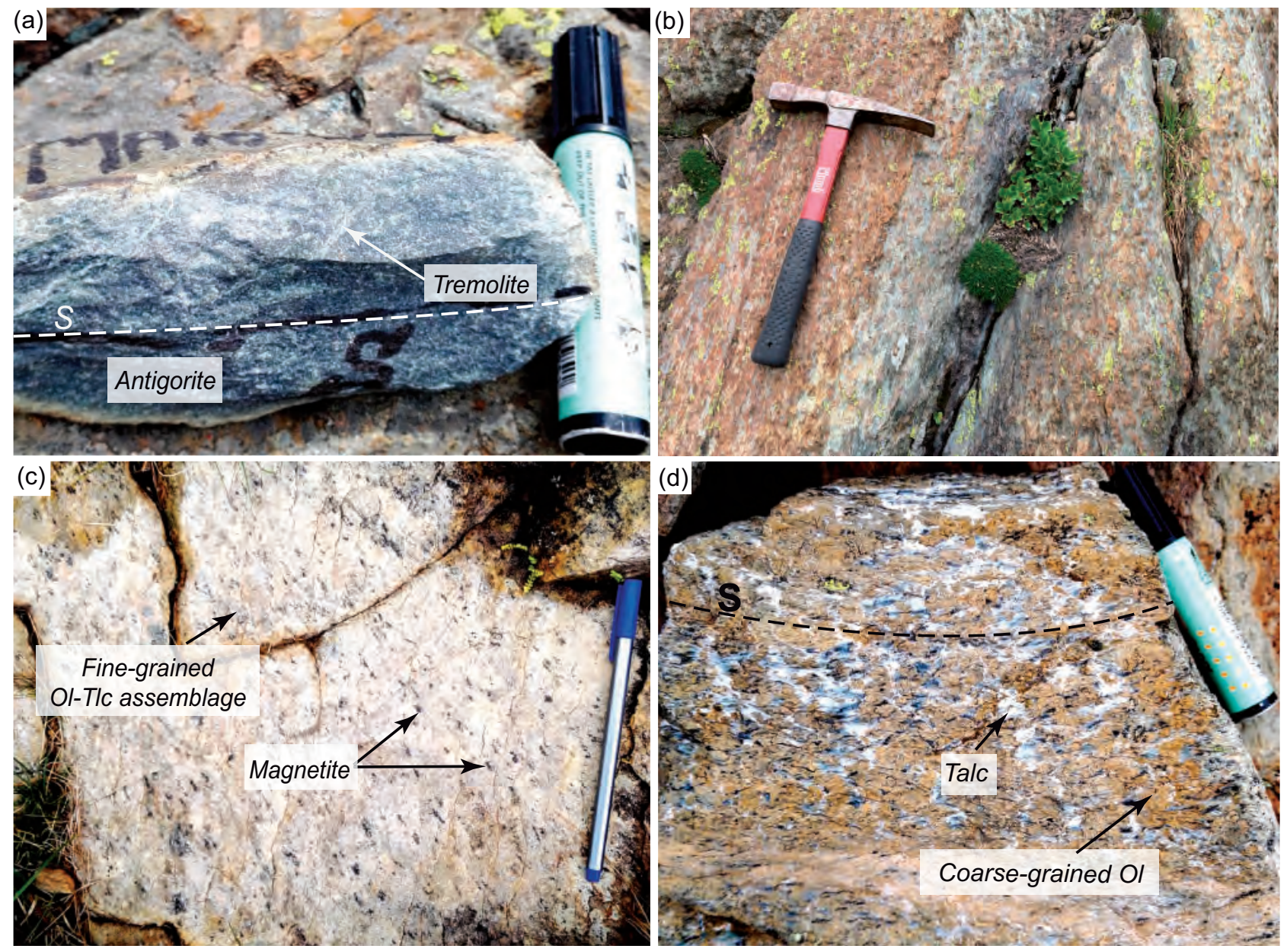

Fig. 3. Representative mesoscopic textures. (a) Tr-bearing serpentinite with a poorly defined foliation (sample MA16-34). (b) Partially reacted serpentinite from the $\sim 150 \mathrm{~m}$ wide reaction front between the serpentinites and pervasive metaperidotites with Ol-Tlc patches of variable dimensions, from several tens of centimeters wide (below the hammer) to a few centimeters wide in the right side of image. (c) Fine-grained OI-Tlc metaperidotite with a weak lineation marked by the elongation of magnetite aggregates (sample MA17-39). (d) Coarse-grained Ol-Tlc-Chl metaperidotite with a coarse foliation and compositional layering marked by alignment of talc-rich domains and a shape-preferred orientation of olivine (MA16-48).

$\mathrm{Ol}+\mathrm{Tr}$, most often as centimetric crystals, although millimeter-size crystals also occur. At the outcrop scale, multiple subparallel or interconnected veins with a spacing of tens of centimeters are observed with sharp limits at the outcrop scale (Fig. 4a). Locally conjugate pairs of veins were observed.

Ol-Tlc veins are notably observed in the serpentinites just downstream of the Tlc-in isograd and in the transition domain, which is characterized by partial (patchy) transformation of the serpentinites into Ol-Tlc metaperidotites [reaction (3); Fig. 1c]. In the field, OI-TIc veins appear dominantly reddish, with white patches between olivine grains corresponding to talc (Fig. 4b-f). Ol-Tlc veins are tens of centimeters wide and several meters long. Some veins display an outward growth of tabular olivine crystals oriented perpendicular to the vein trend (Fig. 4b). Ol-Tlc veins have a wide range of morphologies from channel-like branching shapes to more planar structures (Fig. 4b and c). Locally, they occur as multiple subparallel veins, forming locally en echelon overlaps, or have criss-crossing structures with conjugate or more complex configurations. The thinnest Ol-Tlc veins are formed by discontinuously aligned centimeter-long olivine crystals; this arrangement results in a boudinaged-like aspect of the vein, but olivine crystals in the vein have prismatic shapes (Fig. 4c).

$\mathrm{Ol}-\mathrm{Tlc}$ veins display a wide variation in morphology and size of olivine crystals. However, most Ol-Tlc veins are composed of coarse $(>1 \mathrm{~cm})$ prismatic to blade-like olivine crystals, with the long axes arranged in crisscross, radial, or parallel patterns within the vein plane (Fig. 4e). This texture has been previously described as 'jackstraw olivine' texture (Evans \& Trommsdorff, 1974a; Snoke \& Calk, 1978; Bakke \& Korneliussen, 1986). It is most characteristic when viewed in the plane of the vein, where the long axes of the olivine crystals are concentrated (Fig. 4e). The coarsest olivine grains observed in the study area are up to $20 \mathrm{~cm}$ long, but olivine crystals up to $1 \mathrm{~m}$ long, associated with talc and magnesite, have been reported in the Malenco ultramafic unit by Evans \& Trommsdorff (1974a). Veins with significantly smaller olivine sizes $(0.5-1 \mathrm{~cm})$, but also 

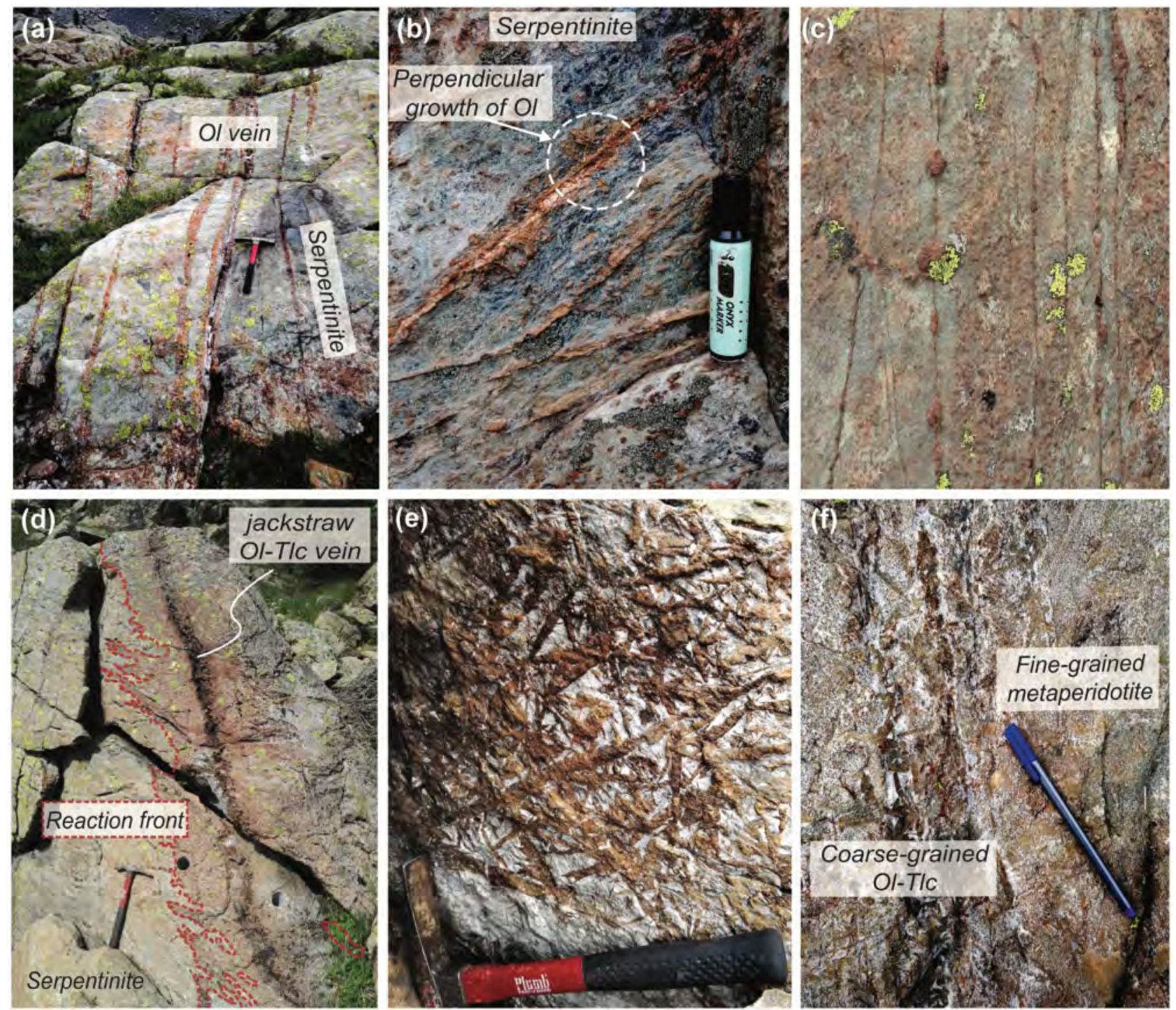

Fig. 4. Representative occurrences of dehydration veins. (a) Multiple sharp and thin Ol veins occurring downstream of the isograd of reaction (2). (b) Multiple Ol-Tlc veins crosscutting the foliation of the serpentinite matrix; the wider vein displays outward growth of prismatic Ol crystals oriented normal to the vein plane. (c) Multiple, thin, subparallel Ol-Tlc veins crosscutting partially reacted serpentinites (approximate width of the image is $40 \mathrm{~cm}$ ). The vein in the center of the image is formed by discontinuously aligned centimeter-long olivine crystals; this arrangement results in a boudinaged-like aspect. (d) Jackstraw-textured Ol-Tlc vein with a wide reaction front with fingering-like contacts with the host serpentinite. (e) View in the plane of the vein of a jackstraw-textured Ol-Tlc vein, showing decimeter-size elongated olivines arranged in a criss-cross pattern. (f) Jackstraw-textured vein crosscutting a fine-grained metaperidotite (MA17-36).

displaying a jackstraw texture, have also been observed. In the metaperidotites, some structures are interpreted as OI-Tlc veins based on their coarser olivine grain size and the change in texture (mainly the olivine SPO, which is jackstraw-like) relative to the host metaperidotite (Fig. 4f).

In addition, Ol-Tlc veins are commonly texturally composite. Composite Ol-Tlc veins are characterized by a central domain in which olivine has a jackstraw texture surrounded by a reaction zone in which olivine crystals are elongated at high angle to the vein, but parallel to the serpentinite foliation in the wall-rock. These reaction zones may be one olivine crystal wide $(\leq 1 \mathrm{~cm}$, Fig. $4 \mathrm{~b}$ ) up to $10-20 \mathrm{~cm}$ wide (Figs $4 \mathrm{~d}$ and 5 ). The wider ones may display finger-like shape limits (Fig. 4d) or be planar at the hand sample scale (Fig. 5). Reaction fronts are texturally similar to pervasive metaperidotites. More rarely, Ol-Tlc veins display a jackstraw-textured domain in sharp contact to the serpentinite, with no associated reaction front. The contact with the serpentinite is irregularly shaped, but no more than a few millimeters wide.

\section{PETROGRAPHY}

\section{Serpentinites and pervasively reacted metaperidotites}

Ca-free serpentinites are mainly composed of finegrained antigorite crystals (Fig. 6a and b). They also 


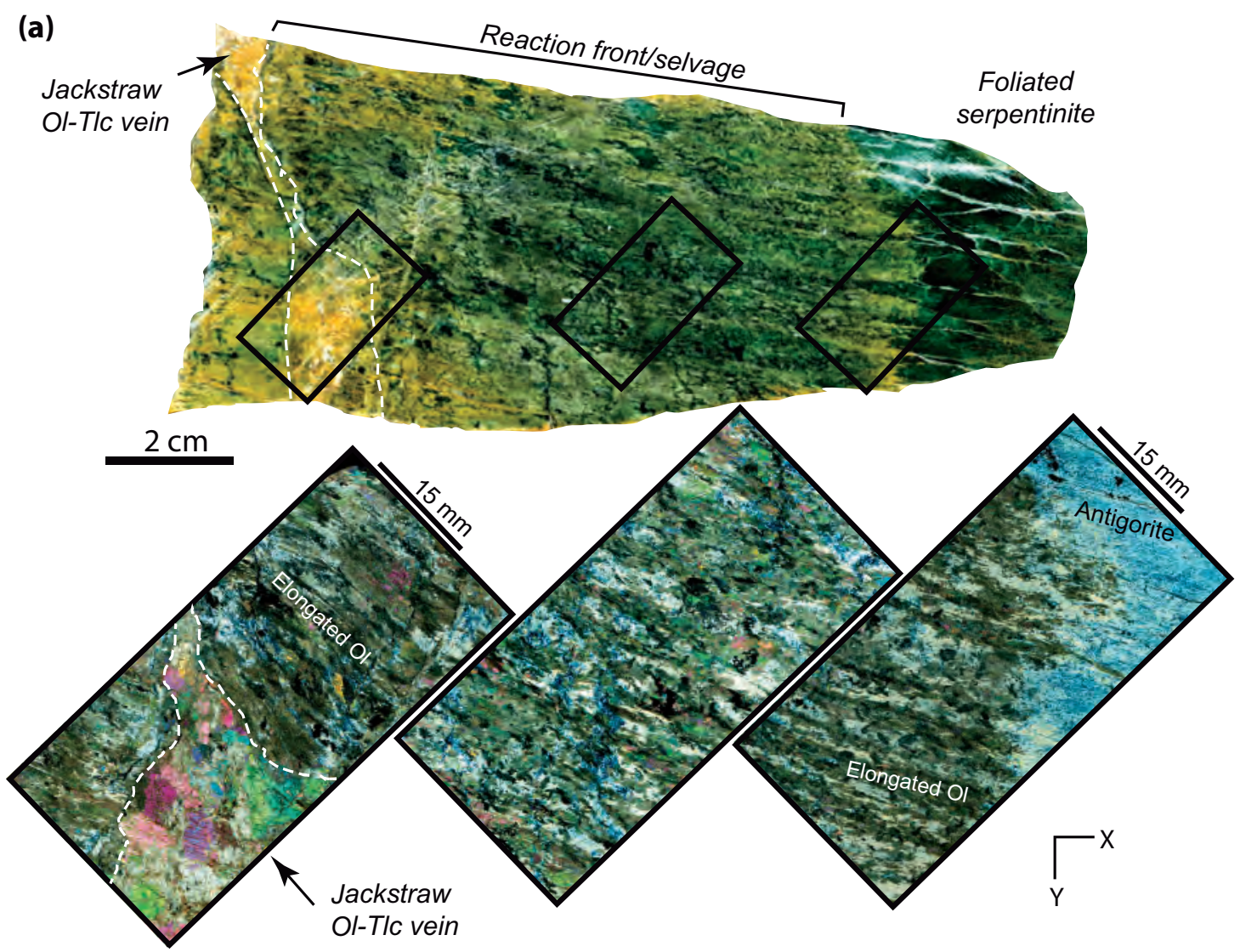

(b)

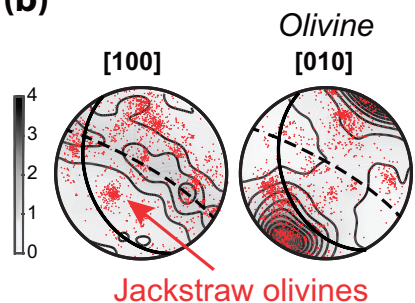

vein orientation

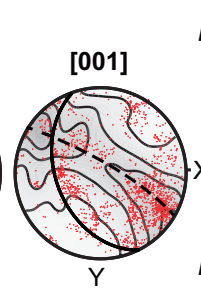

$[001]$

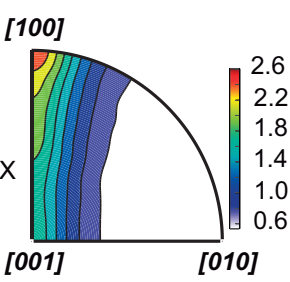

Antigorite
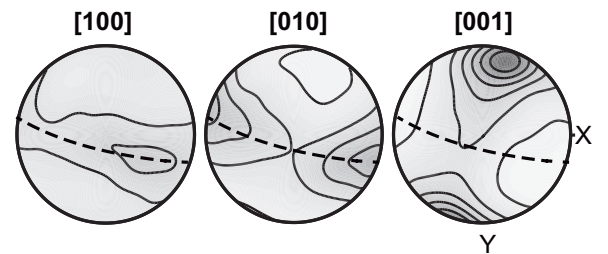

foliation plane

Fig. 5. (a) Macroscopic image and photomicrographs of a composite Ol-Tlc vein with a jackstraw-textured central domain, a wide reaction zone (selvage), and a centimeter-wide fingered contact with the serpentinite wall-rock (MA17-47). The reaction zone displays elongated olivine marking a foliation parallel to the foliation of the serpentinite wall-rock. (b) Pole figures showing the crystal preferred orientation of antigorite in the serpentinite wall-rock and of olivine in the reaction zone (contours) and in the jackstrawtextured central domain of the vein (red points). Inverse pole figure showing the rotation axes accommodating intragranular misorientations in olivine within the reaction front.

contain isolated olivine porphyroblasts with irregular, but sometimes elongated shapes (up to $2 \mathrm{~cm}$ long). The SPO of antigorite and occasionally the elongation of olivine porphyroblasts marks the foliation. Serpentinites also contain magnetite crystals, which form elongated aggregates marking a lineation.

Ca-rich serpentinites are also foliated (Figs $3 a$ and 6c). At the microscopic scale the foliation is marked by the orientation of antigorite and of acicular crystals of tremolite, which are $\sim 200 \mu \mathrm{m}$ long. Olivine in Ca-rich serpentinites occurs as aggregates of rounded finegrained crystals $(<10 \mu \mathrm{m}$ in diameter) or as larger porphyroblasts $(>200 \mu \mathrm{m}$ long) with irregular shapes (Fig. 6d). Locally, crystals of olivine in textural equilibrium with tremolite are observed (Fig. 6d), indicating that they result from reaction (2). Magnetite forms aggregates, which have highly variable shapes and are sometimes aligned, marking a lineation (Fig. 6c).

Partially reacted serpentinites are composed of variable amounts of antigorite and $\mathrm{OI}+\mathrm{Tlc} \pm \mathrm{Tr}$ in diffuse patches. They often contain coarse olivine crystals (up to $1 \mathrm{~cm}$ long and $300 \mu \mathrm{m}$ wide) either isolated or in aggregates. Both the individual olivine crystals and the aggregates are elongated in the foliation plane defined by the antigorite shape-preferred orientation (Fig. 6e and f). Talc occurs either associated with olivine (Fig. 6f) or as diffuse layers parallel to the foliation in the 

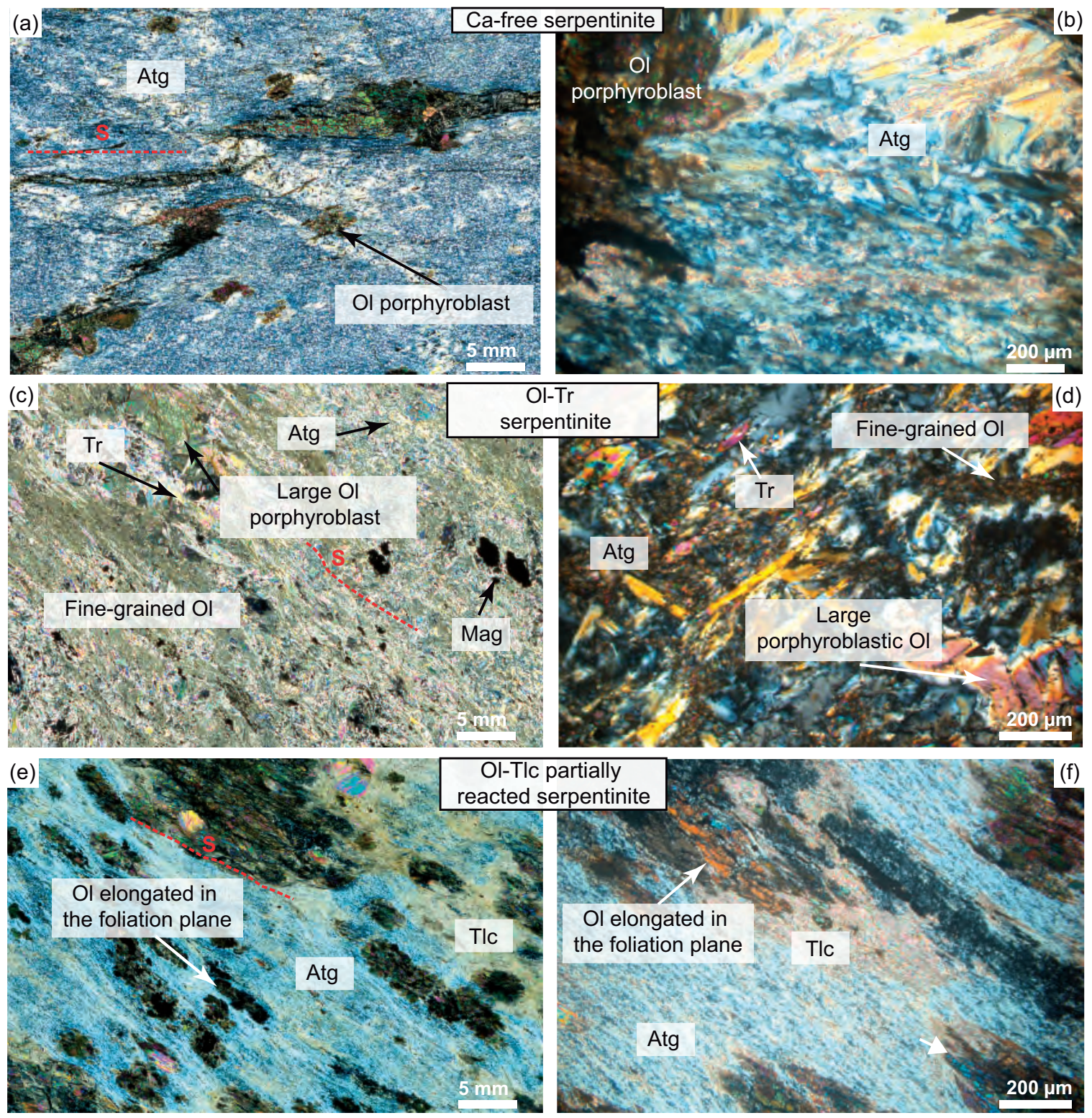

Fig. 6. Optical photomicrographs under cross-polarized light of representative serpentinite and transitional textures from Alpe Zocca $(a, c, e)$ and corresponding enlarged areas (b, d, f). (a) Ca-free serpentinite containing olivine porphyroblasts and fine-grained antigorite (MA16-08). (b) Variations in antigorite orientation and grain size. (c) Ca-rich serpentinite with tremolite and olivine in textural equilibrium (MA16-36). (d) Fine $(<20 \mu \mathrm{m}$ in length) and coarse $(>100 \mu \mathrm{m})$ olivine porphyroblasts coexisting with tremolite and antigorite. (e) Heterogeneously and partially reacted serpentinite with $\sim 50 \%$ of antigorite and $\sim 50 \%$ of Ol-Tlc (MA16-42). (f) Anhedral olivine crystals with serrated boundaries against talc, but elongated in the foliation plane (S).

antigorite matrix. Olivine crystals do not display fully developed crystallographic faces, but have highly irregular grain boundaries (Fig. 6f). They contain common antigorite or tremolite inclusions and are sometimes poikilitic.

Metaperidotites have highly variable microstructures, characterized by changes in shape and size of olivine and in the modal proportion of talc. Most often, metaperidotites are composed of a fine-grained assemblage of small prismatic olivine crystals $(\sim 20 \mu \mathrm{m}$, aspect ratio $<2$ on average) and talc flakes, whose alignment marks a poorly developed foliation (Fig. 7a). Magnetite aggregates up to $5 \mathrm{~mm}$ long are aligned in the foliation, marking a lineation (Fig. 7a). These aggregates are composed of rounded magnetite crystals intercalated with domains enriched in olivine and/or talc, which are oriented normal to the aggregate elongation, similar to extensional cracks (Fig. 7b). Antigorite-rich patches, usually a few millimeters wide, are observed in many metaperidotites at the thin-section scale.

Variations in olivine grain size and shape (probably associated with the orientation of the crystal) occur in a diffuse manner at the millimeter to centimeter scale, as illustrated in Fig. 7c, where a fine-grained metaperidotite with olivine $<20 \mu \mathrm{m}$ in diameter grades into a medium-grained peridotite with olivines $>100 \mu \mathrm{m}$ long 

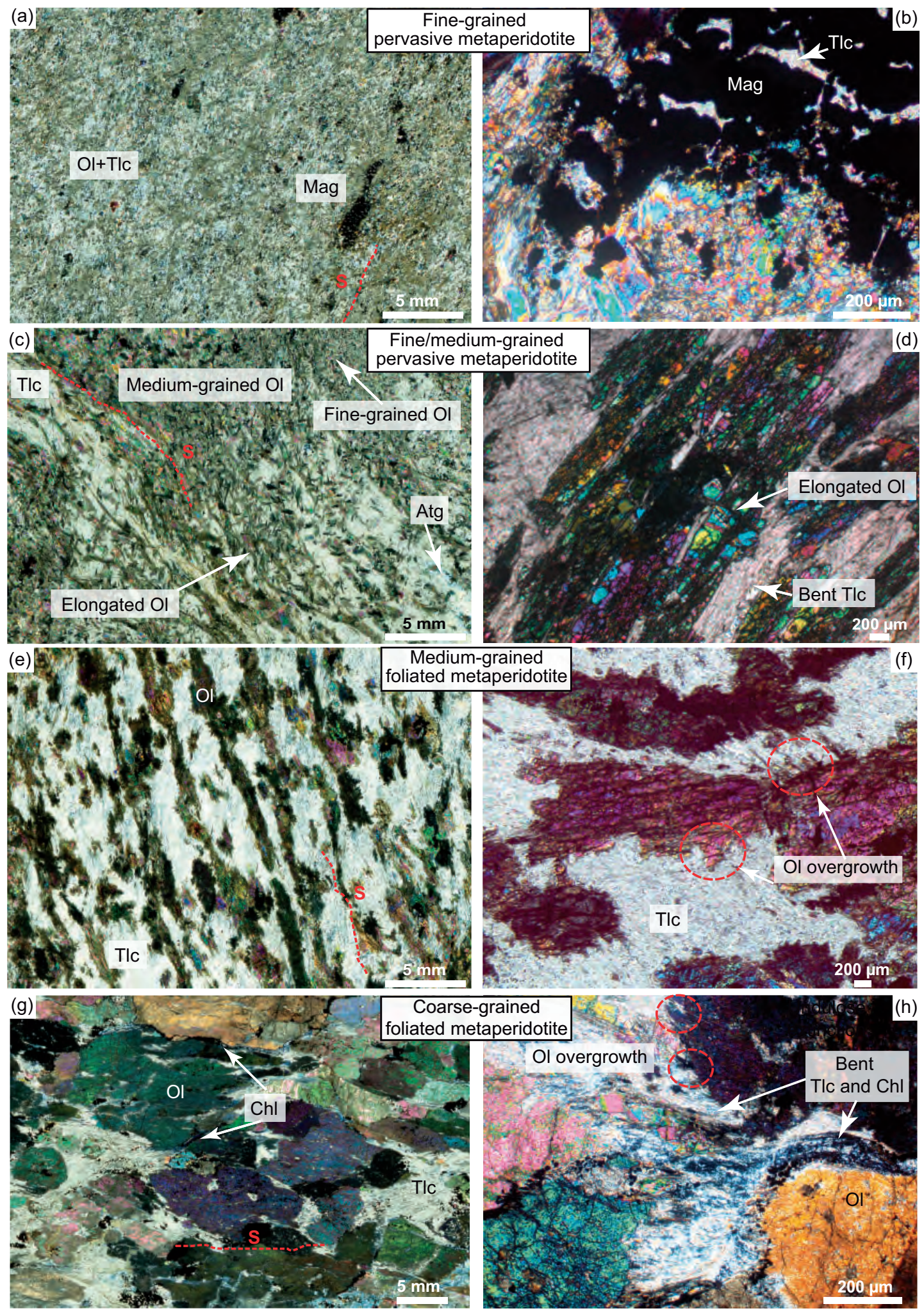

Fig. 7. Optical photomicrographs under cross-polarized light of representative textures of pervasive metaperidotites from Alpe Zocca $(a, c, e, g)$ and corresponding enlarged areas (b, d, f, h). (a) Fine-grained OI-Tlc metaperidotite with aggregates of magnetite crystals elongated in the foliation plane (S) (MA17-34). (b) Detail of magnetite aggregates showing extensional crack-like features filled by talc. Olivine grain size is on average $\sim 20 \mu \mathrm{m}$ (c) Medium-grained Ol-Tlc metaperidotite with a foliation affected by open folds and a bimodal olivine grain-size distribution (either higher or lower than $200 \mu \mathrm{m}$ in length) (MA17-31) (d) Medium-grained elongated olivine with an SPO marking the foliation plane. Talc crystals are occasionally bent between olivine grains. (e) Mediumgrained pervasive metaperidotite with elongated olivine crystals defining a foliation plane parallel to the compositional layering defined by alternating olivine-rich and talc-rich bands. (f) Detail illustrating the coexistence of undulose extinction and irregular overgrowths in olivine grains (MA17-36). (g) Coarse-grained Ol-Tlc metaperidotite (sample MA16-48, shown in Fig. 3d). Olivine crystals show distinct undulose extinction. (h) Detail showing the serrated, dendritic-like overgrowths at the edge of olivine crystals as well as chlorite and talc flakes bent around olivine crystals. 
that are often slightly elongated, marking a poorly defined foliation. Metaperidotites with medium-grained olivine (millimeter-size crystals) frequently have a clear foliation marked by the orientation of prismatic olivine crystals and talc flakes (Fig. 7e). Coarse-grained metaperidotites are composed of centimeter-long olivine crystals with prismatic or, more rarely, skeletal shapes flattened in the foliation plane (Fig. $7 \mathrm{~g}$ ). Independently of grain size, olivine crystals usually show undulose extinction and talc or chlorite crystals are often bent around olivine grains (Fig. $7 \mathrm{~d}$ and h). Olivine crystals have fingering contacts with talc, owing to millimeterwide dendritic-like overgrowths (Fig. $7 f$ and h), but more regular contacts with other olivine crystals (Fig. 7g).

\section{Metamorphic veins}

$\mathrm{OI}-( \pm \mathrm{Tr})$ veins have usually sharp contacts with the surrounding serpentinite at the macroscopic scale, but the contacts are always diffuse at the thin-section scale. OI veins are mainly composed of centimeter-scale olivine crystals (Fig. 8a), but occasionally they may be constituted of fine-grained rounded to polygonal olivine crystals. In thin (centimeter-wide or smaller) coarse-grained veins, olivine crystals in the centre of the vein are elongated parallel to its trend, whereas olivine crystals growing outward from the vein are dominantly elongated at high angles to the vein trend and parallel to the foliation of the serpentinite (Fig. 8b).

Jackstraw-textured Ol-Tlc veins are characterized by prismatic, blade-like or, more rarely, skeletal olivine crystals arranged in a criss-cross or radial pattern (Fig. 8c-f). Antigorite is never present in jackstraw-textured Ol-Tlc veins. Olivine crystals usually show fingering contacts with talc (dendritic-like overgrowths, Fig. 8d and f). Olivine-olivine contacts tend to be polygonal (Fig. 8c). Olivine crystals tend to be coarser (pluricentimetric) in veins containing interstitial carbonates (Figs 4d and 8c), as noted by Evans \& Trommsdorff (1974a). Olivine in carbonate-free veins is most often millimetric to centimetric (Fig. 8d-f), but locally very large prismatic crystals may be observed (Fig. 8f). Talc is typically fine-grained and randomly oriented (Fig. 8df). Olivine crystals are usually undeformed (no undulose extinction, nor sub-grains). In some veins, olivine grains display locally undulose extinction, but preserve the fingering grain boundaries with talc (Fig. $8 \mathrm{e}$ and f). In these veins, talc crystals are bent around olivine (Fig. $8 \mathrm{e}$ and f). Ol-Tlc veins enclosed in the coarse-grained metaperidotites of the pervasively reacted domain share many similarities with those in the serpentinites and partially reacted serpentinites, but their limits are difficult to define (Fig. 8f).

\section{BULK-ROCK COMPOSITIONS}

Bulk-rock compositions of representative samples (Table 1 ) are displayed in a projected $\mathrm{MgO}-\mathrm{SiO}_{2}-\mathrm{H}_{2} \mathrm{O}$
(MSH) ternary diagram using CSpace (Torres-Roldán et al., 2000). Mineral and bulk-rock analyses were projected from the average composition of tremolite, chlorite, and magnetite and the exchange vector $\mathrm{Fe}_{-1} \mathrm{Mg}_{1}$, $\mathrm{Mn}_{-1} \mathrm{Mg}_{1}$ and $\mathrm{Ni}_{-1} \mathrm{Mg}_{1}$ (Fig. 9). In addition to measured bulk-compositions, the projections also include calculated bulk compositions based on modal compositions estimated from the EBSD maps and on mineral compositions measured by EPMA (average composition of antigorite, olivine, talc, tremolite, chlorite, and diopside for representative samples is shown in Supplementary Data Tables 1S-6S; supplementary data are available for downloading at http://www.petrology.oxfordjour nals.org). Measured and calculated compositions for serpentinites plot close to the antigorite pole (Fig. 9); the dispersion results from variable olivine contents. Pervasive metaperidotites plot on the talc-olivine tie-line (Fig. 9). The observed range in talc and olivine proportions (i.e. relative proportion of the projected components $\mathrm{MgO}$ vs $\mathrm{SiO}_{2}$ ) is within the projected $\mathrm{MgO} /$ $\mathrm{SiO}_{2}$ ratio in the serpentines (antigorite with a variable proportion of olivine; blue field in Fig. 9). Jackstraw-textured Ol-Tlc veins globally plot in the same field as the pervasive metaperidotites. Some reactional walls of large veins such as the one illustrated in Fig. 5 show evidence for $\mathrm{SiO}_{2}$ depletion, which moves the bulk-rock composition along the antigorite-olivine tie-line (Fig. 9). Such zones can be interpreted as selvages or alteration halos characteristic of extreme fluid channelization (e.g. Ague, 2011). Calculated compositions of partially reacted serpentinites plot inside the Atg-Tlc-Ol field (Fig. 9). Some of these lithologies might correspond to a true divariant (or higher) mineral assemblage in the full chemical system, but in most cases the three-phase assemblage is simply related to an incomplete dehydration of antigorite (i.e. heterogeneous distribution of metastable antigorite patches or septa; see Frost, 1975).

\section{CRYSTAL PREFERRED ORIENTATIONS}

\section{Serpentinites and pervasive metaperidotites}

An outstanding feature of the study area is the consistency of the orientation of the foliation in the serpentinites and in the pervasive metaperidotites. We investigate the potential crystallographic inheritance from antigorite to olivine by comparing the CPOs of both minerals at the thin-section scale in samples recording different degrees of transformation through reactions (2) and (3). In the serpentinites and partially reacted serpentinites, antigorite is dispersed in the matrix (Fig. 6a-f). In the metaperidotites, it occurs as discontinuous patches or septa in the dominantly Ol$\mathrm{Tlc} \pm \mathrm{Tr}$ rock-mass. Figure 10 illustrates the evolution of the relationship between antigorite and olivine CPOs along a profile approximately normal to the contact with the Bergell intrusion, shown as a black line in Fig. 1c. All pole figures were projected in the geographical reference frame (inset in Fig. 10). When measured in the field, the orientation of the foliation is indicated 



Fig. 8. Optical photomicrographs of representative veins from Alpe Zocca under cross-polarized light. (a) Upper left: OI vein composed of pluricentimetric olivine crystals (MA17-13). Lower right: OI vein composed of equant millimetric olivine grains (MA17-16). (b) Irregular OI vein characterized by a thin central domain composed of aligned olivine crystals elongated parallel to the vein trend and by olivine crystals elongated perpendicular to the vein trend along its borders (MA17-17). (c) Jackstraw-textured OI-Tlc vein (thin section roughly parallel to the vein plane) composed of blade-like olivine grains (centimeter-long) arranged in a crisscross pattern and low amounts of coarse-grained interstitial talc (MA16-12) (e) Medium-grained jackstraw-textured Ol-Tlc vein in which two sets of aligned, elongated olivine crystals crosscut the criss-cross structure (MA16-57). (e) Deformed jackstraw-textured Ol-Tlc vein in direct contact with the host-rock serpentinite (MA17-23). (f) Deformed coarse-grained Ol-Tlc vein in the pervasive metaperidotite domain (MA16-46). Some olivine crystals in the vein have undulose extinction and talc crystals are often bent.

by a continuous line in the $[001]_{A t g}$ and $[010]_{O I}$ pole figures. The plane normal to the $[001]_{A t g}$ and $[010]_{O I}$ maxima is indicated as a dashed line for comparison.

Antigorite and olivine in all studied samples have a clear CPO. The strength of the CPO of the two minerals is usually correlated. Weak antigorite CPOs are associated with weak olivine CPOs and vice versa (Fig. 10). Antigorite in the serpentinites and in small unreacted patches in the pervasive metaperidotites shows similar CPOs (Fig. 10). [001] Atg is concentrated normal to the foliation, but with some dispersion in the plane normal to the $[010]_{\text {Atg }}$ maximum. $[010]_{\text {Atg }}$ is dispersed in a girdle subparallel to the foliation plane with a maximum in this plane. $[100]_{\text {Atg }}$ usually shows more dispersed orientations, but also tends to form a girdle subparallel to the foliation plane. When a lineation could be inferred from the orientation of magnetite aggregates, it did not show a clear correlation with either $\left[{ }^{100}\right]_{A t g}$ or $[010]_{A t g}$.

In most talc-bearing metaperidotites, olivine displays a strong concentration of [010] ox axes at low angle to the $[001]_{\text {Atg }}$ maximum and at high angle to the foliation, when the latter could be measured in the field (Fig. 10). 




Fig. 9. Projected ternary diagram in the $\mathrm{MgO}-\mathrm{SiO}_{2}-\mathrm{H}_{2} \mathrm{O}(\mathrm{MSH})$ system for measured bulk compositions (circles) and bulk compositions calculated based on modal proportions obtained from EBSD data and average mineral compositions (squares). Projections were performed from tremolite, chlorite, magnetite and vectors $\mathrm{MgFe}_{-1}, \mathrm{MgMn}_{-1}, \mathrm{MgNi}_{-1}$ (computed using CSpace; Torres-Roldán et al., 2000). Serpentinites plot along the Atg-OI tie-line, whereas pervasive metaperidotites and veins plot along the Ol-Tlc tie-line. Ca-rich serpentinites are indicated by yellow outlines around the symbols. The proportion of Ol and Tlc in the metaperidotites is in the expected range based on the compositional variability observed in serpentinites (blue field). Ol-Tlc-Atg three-phase assemblages correspond to partially and heterogeneously reacted serpentinites from the $150 \mathrm{~m}$ wide reaction front associated with reaction (3); they do not represent an equilibrated mineral assemblage.

$[100]_{\mathrm{OI}}$ and $[001]_{\mathrm{OI}}$ axes usually form girdles normal to the $[010]_{\mathrm{O}}$ maximum, with poorly defined mutually orthogonal maxima within the girdle (e.g. samples MA1731 and MA16-45 in Fig. 10). This CPO pattern corresponds to relatively low BC-indices ( $\leq 0.35$, Fig. 11a). Other samples (e.g. MA16-43 in Fig. 10) display more orthogonal olivine CPO patterns, characterized by three orthogonal maxima, resulting in higher $\mathrm{BC}$-indices $(\geq 0.5$, Fig. $11 \mathrm{a})$. In these samples, $[001]_{O}$ is usually better oriented than $[100]_{\mathrm{OI}}$. The remainder of the samples have olivine CPO patterns intermediate between these two end-members. This CPO is associated with an SPO: olivine crystals are usually prismatic, elongated parallel to [001] and flattened parallel to [010]. However, the difference in elongation between [010] and [100] is probably small, as crystals oriented with [001] normal to the thin section are roughly isometric. When present in pervasive metaperidotites (e.g. MA17-31), tremolite has [001] axes forming a girdle in the foliation plane and [010] axes aligned normal to the foliation plane, parallel to the $[010]_{\mathrm{O}}$ maximum.

In talc-free serpentinites, the relation between olivine and antigorite CPO is variable. Serpentinite MA16-08, sampled close to the isograd from reaction (3), shows, like the metaperidotites, concentration of [010] $]_{\mathrm{O}}$ axes at low angle to the $[001]_{\text {Atg }}$ maximum (Fig. 10). However, serpentinites MA16-36 and MA16-34, sampled farther from the Bergell intrusion contact, in which olivine probably results from reactions (2) and/or (1b), respectively, have $[100]_{\mathrm{O}}$ axes, rather than $[010]_{\mathrm{O}}$, oriented subparallel to the $[001]_{\text {Atg }}$ axes.

There is neither correlation nor anti-correlation between the strength of olivine CPO and the distance to the Bergell intrusion (Fig. 10). This observation is corroborated by the analysis of a larger number of metaperidotites (30 samples) with variable grain sizes, which shows that neither the intensity of the olivine CPO ( $J$-index) nor its symmetry (BC-index) varies in a systematic way with increasing distance to the intrusion (Fig. 11). Axial-[010] olivine CPO (BC-index $<0.35)$ and orthorhombic olivine CPO (BC-index between 0.35 and 0.65) predominate (Fig. 11a). Axial-[001] textures (BCindex $>0.65)$ are rare. There is also no clear relation between the olivine CPO intensity or symmetry and grain size, although fine-grained metaperidotites tend to have dominantly weak fabrics ( $J$-index $\leq 2$, Fig. 11b).

\section{Metamorphic (dehydration) veins}

Figure 12 illustrates the CPO of olivine and, when present, tremolite, in dehydration veins as well as the antigorite CPO in the serpentinite from the wall-rock at the contact with the vein. There is no correlation between the CPO of the antigorite outside the vein and the olivine or tremolite CPO in the vein, except in those rare cases where the vein cuts the serpentinite foliation at low angle (e.g. MA17-16).

In talc-free veins, olivine grains are either weakly oriented (MA17-16) or, because of the coarse grain sizes, the number of grains analysed is too low (MA17-47 in Fig. 5 and MA17-10 and MA17-17 in Fig. 12) to define a representative $\mathrm{CPO}$ (the multiple maxima correspond to large individual crystals, with some growth-related internal mis-orientation). However, the [010] axes of olivine tends to align at high angle to the plane of the vein (indicated by a continuous great circle in the $[010]_{\mathrm{O}}$ pole figures in Fig. 12), whereas [100] and [001] axes form wide girdles at low angle to this plane. This relation between olivine CPO and vein orientation is better 




Fig. 10. Pole figures of antigorite and olivine from representative samples along the profile shown in Fig. 1c. Shaded pole figure is for tremolite. Orientations (average orientation of the grain) were plotted in lower hemisphere projections in the geographical reference frame contoured at one multiple of uniform distribution intervals. The continuous line indicates foliation planes measured in the field, whereas dashed lines mark the planes normal to the $[001]_{\text {Atg }}$ and $[100]_{O I}$ or $[010]_{O I}$ maxima. S, S-r and M refer to serpentinite, partially reacted serpentinite, and metaperidotite, respectively. Phase proportions of each sample are indicated by the grayscale bars at the right of the stereoplots. Frames highlight the correlated axes of antigorite and olivine. The number of grains included is indicated as thousands ( $\mathrm{k}$ ). It should be noted that for olivine, the profusion of inclusions makes difficult to correctly identify the grains, therefore the number of grains is probably overestimated.

developed in olivine in jackstraw-textured Ol-Tlc veins (Fig. 12). It is consistent with the observation that jackstraw olivines are elongated in the plane of the vein, but have their long axis, which is usually parallel to [001], oriented in a criss-cross pattern within the plane of the vein (Fig. 4d and e).
The change in olivine CPO and SPO patterns between the veins and the pervasive metaperidotite is reproduced at smaller scale in the composite OI-TIc veins. Figure 5 illustrates the variation in microstructures and olivine and antigorite CPO and SPO in a welldeveloped composite vein characterized by a central 

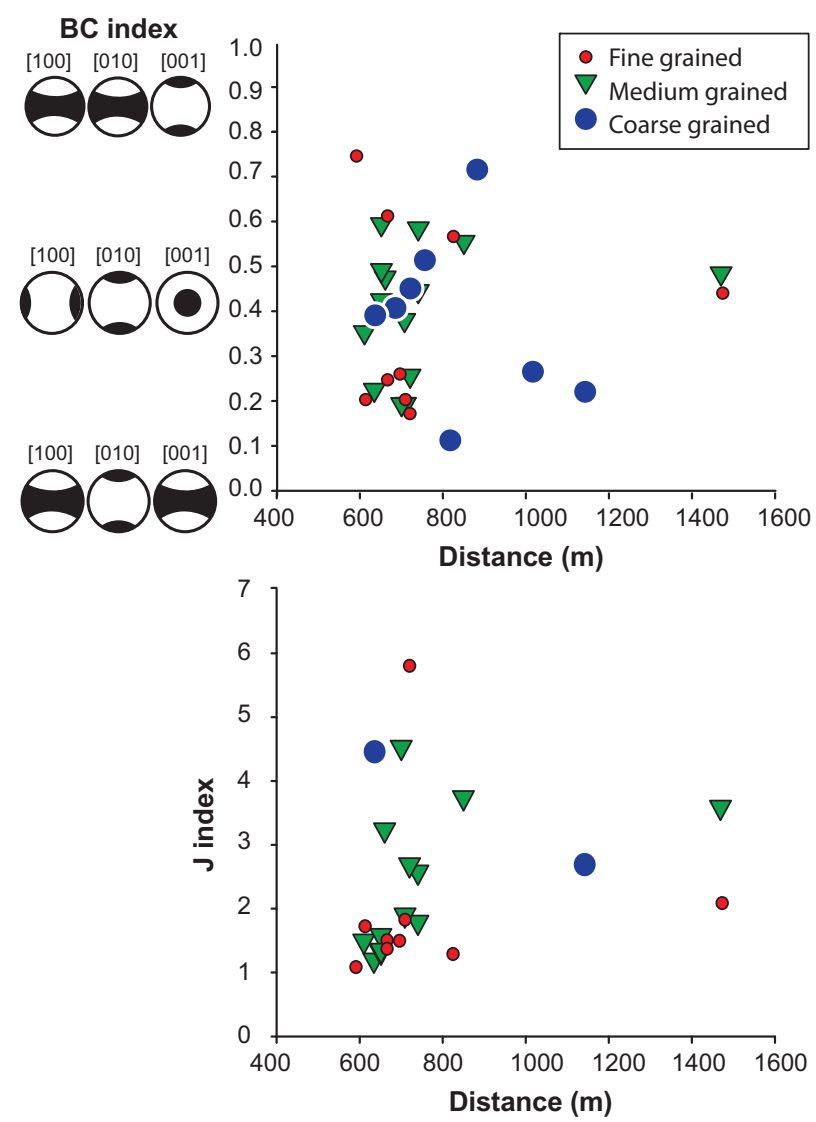

Fig. 11. (a) Symmetry (BC-index) and (b) strength ( $J$-index) of the olivine CPO as a function of distance from the Bergell intrusion. Samples were classified as fine-grained (average olivine grain size $<200 \mu \mathrm{m}$ ), medium-grained (between $200 \mu \mathrm{m}$ and $1 \mathrm{~cm})$, and coarse-grained $(>1 \mathrm{~cm})$.

domain with irregular width (up to $2 \mathrm{~cm}$ ) composed of coarse-grained Ol-Tlc-Tr with a jackstraw texture surrounded by a reaction zone $c .10 \mathrm{~cm}$ wide. The reaction zone is formed by a foliated metaperidotite composed of tabular olivine crystals intercalated with talc. The foliation in the metaperidotite, defined by the SPO of olivine and talc, is parallel to the foliation plane defined by the SPO of antigorite in the serpentinite wall-rock and both are highly oblique to the vein trend (Fig. 5a). At the millimeter scale, the reaction front of the vein has a diffuse, fingered contact with the serpentinite (Fig. 5a). The foliation plane in the reaction zone rotates by $\sim 20^{\circ}$ from the contact to the serpentinite to the centre of the vein. EBSD analyses in the serpentinite and in the reaction zone show strong CPO of both antigorite and olivine, with a similar orientation of the $[001]_{A t g}$ and of the ${ }^{[010]_{\mathrm{O}}}$ axes normal to the foliation in the serpentinite and metaperidotite, respectively (Fig. 5b). The low number of olivine grains that could be analyzed in the central part of vein, which has a jackstraw texture, does not allow definition of a statistically meaningful CPO, but $[010]_{O}$ axes are dominantly at high angle to the general trend of the vein. Similarly to some pervasive metaperidotites, olivines in the reaction zone show undulose extinction. The rotation axes accommodating this intracrystalline mis-orientation are $<\mathrm{u} 0 \mathrm{w}\rangle$ crystal axes, with some predominance of [100] (Fig. 5b).

\section{Olivine intracrystalline misorientation}

Variations in orientation of the crystalline lattice within a crystal $\left(\leq 15^{\circ}\right)$ result essentially from stored dislocations. Clear intragranular mis-orientations around coherent rotation axes are indicative of deformation by dislocation creep. Thus, we analysed the variation of the mean (at the sample scale) intragranular misorientation of olivine in pervasive metaperidotites and in veins as a function of the grain size and of distance to the contact with the Bergell intrusion, as well as the rotation axes accommodating these mis-orientations to characterize the potential viscoplastic deformation of olivine (Fig. 13). Mean intragranular mis-orientations $\geq 4^{\circ}$ are observed only within $900 \mathrm{~m}$ from the contact with the Bergell intrusion, in the domain affected by reaction (3). However, the lack of high mean intragranular mis-orientations farther from the intrusion may be a bias from the less dense sampling of olivine-rich rocks in this domain. Otherwise the mean intragranular misorientation in olivine seems to be uncorrelated with distance from the intrusion. Coarse- and medium-grained metaperidotites (Fig. 13c) have olivine with highly variable average intragranular mis-orientations (from 1 to $6^{\circ}$ ). Fine-grained metaperidotites have a lower range of average mis-orientations (from 1 to $3^{\circ}$ ), but these lower values may result from the lower number of orientation data per grain. Olivine crystals in veins have average intragranular mis-orientations in olivine overlapping with those of medium- to coarse-grained pervasive metaperidotites, but average intragranular misorientations in olivine in veins are on average lower (Fig. 13a). The spatial distribution of intragranular misorientations in olivine in the veins is also usually more heterogeneous (coexistence of deformed and undeformed grains; Fig. 13d) than in the pervasive metaperidotites (Fig. 13c). The mis-orientation data are consistent with petrographic analyses: olivine in metaperidotites and veins displays a large range of microstructures, from barely free of intragranular deformation (Fig. 8c and d) to well-developed undulose extinction associated with bent talc crystals (Figs 7e-h and $8 \mathrm{e}, \mathrm{f}$ ). The rotation axes accommodating intragranular mis-orientations in olivine in pervasive metaperidotites and in veins usually differ (Fig. 13b). They are dominantly $<\mathrm{uOW}>$ with a maximum at [100] in pervasive metaperidotites, similar to those in the reaction zones of composite veins (Fig. 5), whereas in jackstrawtextured domains of Ol-Tlc veins, rotation axes accommodating intragranular mis-orientation in olivine are mainly $\langle 0 \mathrm{vw}\rangle$ with predominance of [010] axes. Some pervasive metaperidotites have rotation axes accommodating intragranular mis-orientations in olivine intermediate between these two dominant cases, with two maxima, one parallel to [100] and the other parallel to [010]. 


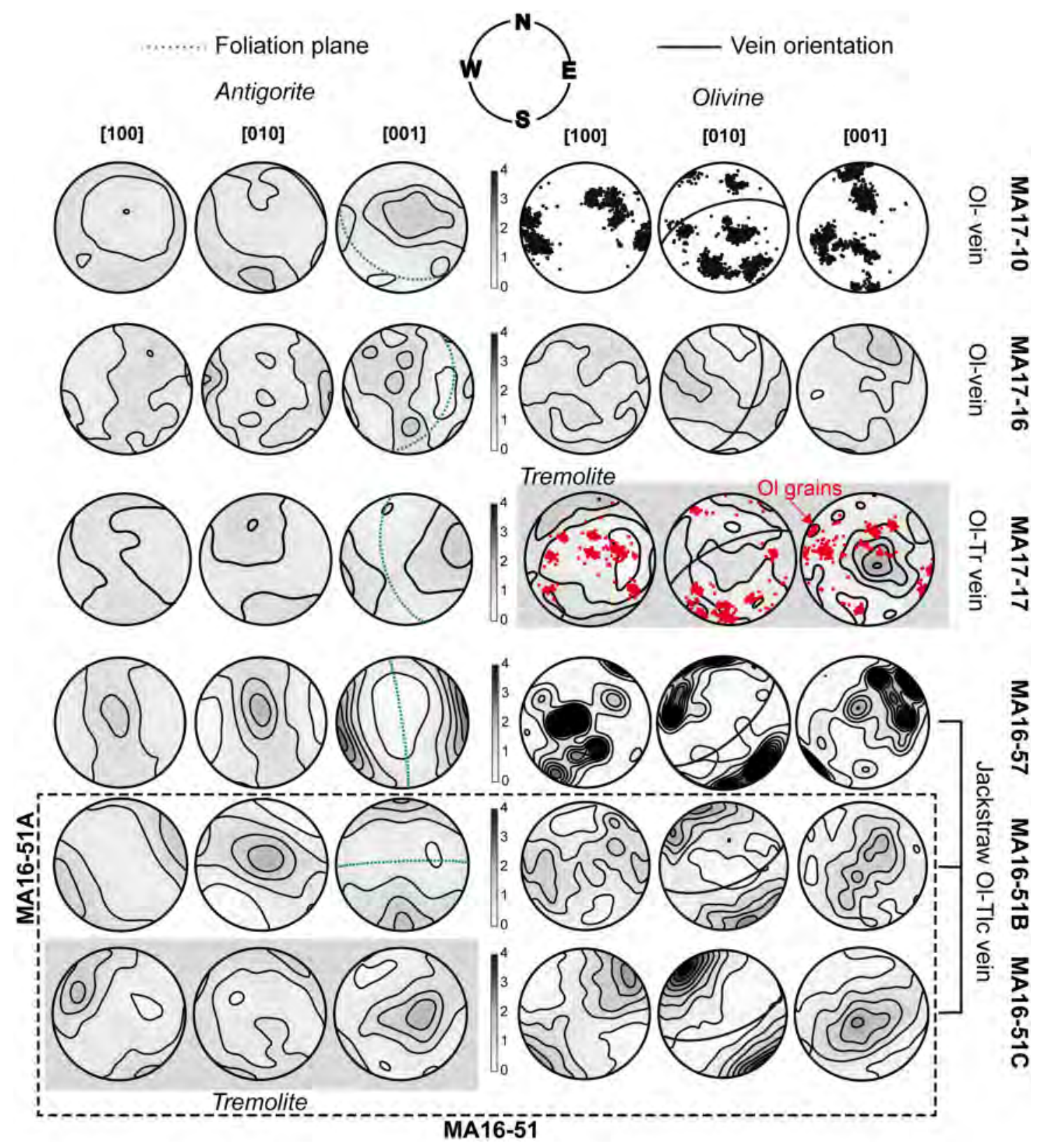

Fig. 12. Olivine pole figures from representative veins and antigorite pole figures from wall-rock serpentinite. Shaded pole figure is for tremolite. Orientations (average orientation of the grain) were plotted in lower hemisphere projections in the geographical reference frame contoured at one multiple of uniform distribution intervals. For the Ol-Tr vein, olivine orientations were not contoured because too few grains could be measured owing to the coarse grain size. The continuous black line indicates the orientation of the plane of the vein measured in the field and the green line marks the foliation plane in the serpentinite wall-rock.

\section{DISCUSSION}

A major observation in the study area is the occurrence of the prograde assemblages formed by reaction (2) and notably by reaction (3) in two contrasting modes: (1) pervasive metaperidotites, most often weakly foliated, separated from the unreacted serpentinites by a $c$. $150 \mathrm{~m}$ wide zone characterized by a patchy mixture of variably reacted rocks; (2) downstream of this 'isograd', metaperidotites within dehydration (replacement) veins, which often have centimeter- to decimeter-scale reaction fronts or selvages propagating towards the unreacted serpentinite wall-rocks. Microstructures and $\mathrm{CPO}$ of the reaction products in the two modes of occurrence differ. We interpret the variation in mode of occurrence and in microstructure of the products of the antigorite dehydration reactions as resulting from different fluid extraction processes and associated reaction conditions. Mode (1) records the progressive and pervasive transformation of the antigorite schists into metaperidotite at near equilibrium conditions, whereas mode (2) records local displacement of the reactions towards lower temperature conditions owing to the 


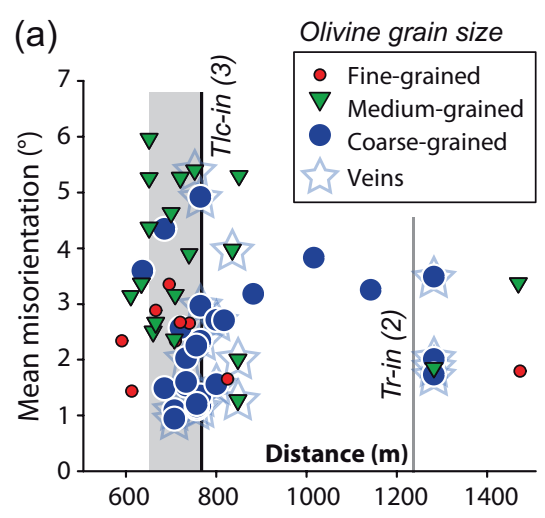

(c) Misorientation to the mean orientation

Pervasive metaperidotite



(b) Low angle misorientation
axis distribution

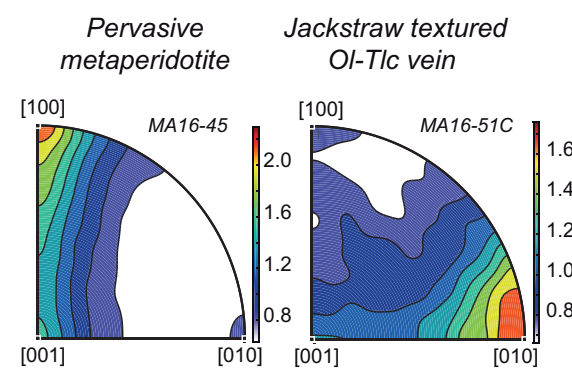

(d) Misorientation to the mean orientation

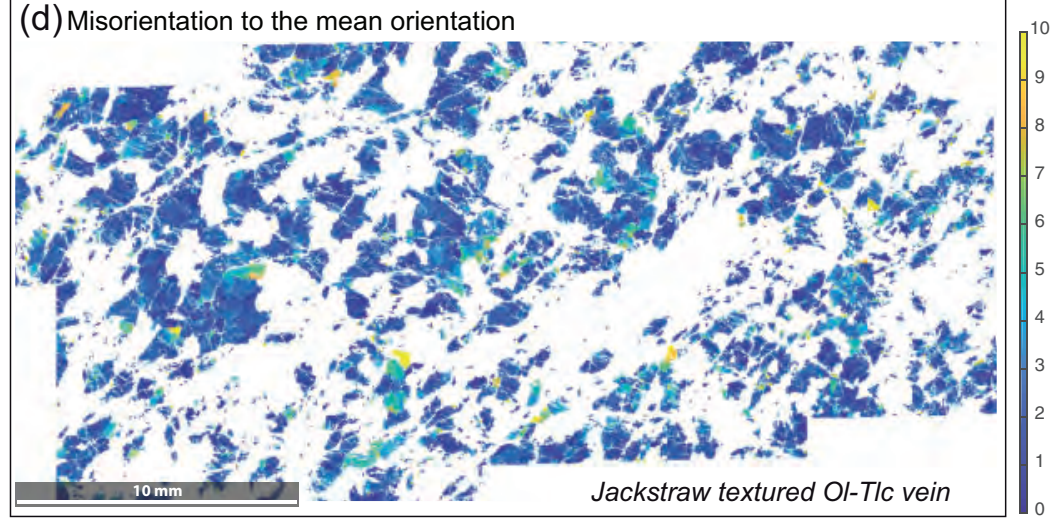

Fig. 13. (a) Mean intragranular olivine mis-orientation as a function of the distance from the Bergell intrusion. Veins are included in the plot; they are mostly coarse-grained. No correlation is observed with distance from the intrusion. (b) Inverse pole figures of intragranular mis-orientation axes for olivines $\left(2-10^{\circ}\right)$ from a representative pervasive metaperidotite (MA16-45) and from a jackstraw-textured OI-TIc vein (MA16-51C). (c, d) Intragranular mis-orientation maps for olivine (mis-orientation relative to the mean orientation M2M) for the two samples.

formation of extensional veins, which acted as high-permeability channels allowing for effective draining of the system.

\section{Pervasive metaperidotites: fluid drainage by viscous compaction}

Pervasive peridotites formed by progressive and pervasive transformation of the antigorite schists into metaperidotite at near equilibrium conditions, as indicated by the development of a $150 \mathrm{~m}$ wide partially reacted domain (Fig. 1c) composed of variably reacted rocks with an irregular, patchy distribution at scales ranging from a few centimeters to a few meters (Figs $3 b$ and 6e, f), and by the systematic preservation of small patches of antigorite in the metaperidotites (Fig. 7c). Growth of elongated olivine over schistose serpentinite and persistence of unreacted serpentine septa over $20 \mathrm{~m}$ were also documented in low-pressure contact metamorphism of ultramafic rocks from Paddy-Go-Easy pass in the Central Cascades (Frost, 1975). The persistence of unreacted serpentine is never observed in the dehydration veins.

In a recent experimental dehydration study (gypsum to bassanite reaction), Leclère et al. (2018) showed that high effective pressure resulted in sharp dehydration fronts separating fully reacted from non-reacted rocks, whereas wide reaction fronts preserving significant amount of unreacted gypsum are produced when the effective pressure is low. Low effective pressure during viscous metamorphic compaction would result in reaction kinetics close to equilibrium, because the reaction affinity remains low when fluid pressure approaches lithostatic pressure (Dahlen, 1992; Padrón-Navarta et al., 2011; Dilissen et al., 2018). Grain growth is then controlled by interface-coupled dissolution-precipitation processes (Putnis, 2002; Putnis \& Putnis, 2007). This may explain the parallelism between the foliation in the serpentinites and metaperidotites (Fig. 2), which results in a consistent fabric at the kilometer scale, across the reaction front. It may also account for the CPO relations between olivine and antigorite in the metaperidotites (Fig. 10), which are consistent with those observed during topotaxial replacement of olivine by antigorite (Boudier et al., 2010).

Under such conditions, viscous compaction has been proposed as an efficient draining mechanism (Connolly, 1997, 2010). The pervasive metaperidotites show evidence for solid-state deformation following their crystallization. Olivine displays undulose extinction (Figs 7 and 13c). Talc and chlorite crystals are bent 
(Fig. 7d and h). However, olivine crystals preserve prismatic shapes and even the delicate fingering contacts with talc (Fig. 7). The latter observation suggests that the solid-state deformation is weak and cannot be responsible for the foliation displayed by these rocks (Figs 3c, d and 7). Yet local variations in foliation orientation observed at the outcrop and sample scale may have resulted from macroscopic-scale compaction. Similar deformation microstructures were documented and attributed to syn-metamorphic viscous compaction in metaperidotites composed of olivine + enstatite + chlorite ( \pm tremolite) with granofels texture in Cerro del Almirez (Padrón-Navarta et al., 2011, 2015; Dilissen et al., 2018). These metaperidotes, formed by antigorite dehydration at higher pressures and temperatures (16$19 \mathrm{kbar}$ and $680^{\circ} \mathrm{C}$, Fig. 1b), display additional evidence for viscous compaction such as shear-induced inversion of orthoenstatite to low clinoenstatite, which allow the stresses involved in this process to be constrained to a few tens of MPa (Padrón-Navarta, 2015; Clément et al., 2018). These stress levels are consistent with predictions of numerical models of viscous metamorphic compaction during dehydration (Connolly, 1997).

Weak deformation of olivine by dislocation creep under such low stresses, and at the low-temperature conditions inferred for the study area $\left(500-600^{\circ} \mathrm{C}\right)$, might be possible, as the metamorphic olivine crystallized under fluid-saturated conditions and had initially high densities of point and planar defects (clinohumite lamellae and/or talc inclusions), but low dislocation densities. Moreover, at the beginning of compaction, stresses may be locally high, as the contact area between olivine grains is small. Stresses decrease with increasing compaction as the contact area increases. Intragranular mis-orientation in olivine in the metaperidotites is associated with rotations around $<\mathrm{u} 0 \mathrm{w}\rangle$ axes, mainly [100], and less often around [010], which is nevertheless the dominant rotation axis accommodating intragranular mis-orientations in vein olivine (Fig. 13b). At low temperature and high stresses and in wet conditions, the dominant slip systems in olivine are [001]\{110\} and [001](100); accumulation of dislocations of these systems should produce rotations around [100] and [010] (e.g. Raleigh, 1968; Mackwell et al., 1985; Demouchy et al., 2013, 2014; Idrissi et al., 2016).

\section{Dehydration veins: reaction triggered by deformation-induced chemical disequilibrium}

Replacement veins resulting from dehydration reactions in open systems have long been known to form at lower temperatures than those expected for the same reactions to occur in a closed system, where the $\mathrm{H}_{2} \mathrm{O}$ fluid pressure equals the confining pressure (e.g. Fyfe et al., 1958; Coombs et al., 1959; Bruton \& Helgeson, 1983; Coombs 1993). Dehydration can indeed proceed at isothermal and isobaric conditions (constant lithostatic conditions) if fluid pressure is allowed to decrease (e.g. Fyfe et al., 1958). The chief variable in such open systems is the chemical potential of the $\mathrm{H}_{2} \mathrm{O}$ component, which needs to be lower than what corresponds to fluid saturation for the given confining pressure (Bruton \& Helgeson, 1983). The seminal work of Greenwood (1961) on the dehydration of analcime using $\mathrm{Ar}$ as inert gas to reduce the chemical potential of $\mathrm{H}_{2} \mathrm{O}$ is an early and elegant experimental confirmation of this model. Joint-controlled replacement reactions resulting in dehydration of the host-rocks at the centimeter to decimeter scale are indeed not unusual in the brittle crust (e.g. Coombs et al., 1959; Coombs, 1993). They have also been described in eclogite-facies conditions as 'prograde-metamorphic dehydration fluid conduits' or dehydration veins owing to an influx of an $\mathrm{H}_{2} \mathrm{O}$-unsaturated fluid (e.g. Beinlich et al., 2010; John et al., 2012; Taetz et al., 2016, 2018).

The most likely origin for the dehydration veins observed in the present study is a sudden change in the $\mathrm{H}_{2} \mathrm{O}$ chemical potential of the system as the result of the formation of extensional fractures, which produced a local pressure decrease and hence a chemical potential gradient. The reduction of the $\mathrm{H}_{2} \mathrm{O}$ chemical potential in the crack may have been triggered by either (1) infilling of the fracture by external fluids rich in other components such as $\mathrm{CO}_{2}$ (e.g. Evans \& Trommsdorff, $1974 b$ ) or (2) release of $\mathrm{H}_{2} \mathrm{O}$-aqueous fluid by dehydration of antigorite, aiming to homogenize the chemical potential gradient created across the crack. The first mechanism may have played a role locally, as some veins have magnesite. Isobaric $(3.5 \mathrm{kbar})$, fluidsaturated $T-X\left(\mathrm{CO}_{2}\right)$ computations for the same bulk composition as used in Fig. 1b [Fig. 1S, Supplementary Data, where $X\left(\mathrm{CO}_{2}\right)$ is the mole fraction of $\mathrm{CO}_{2}$ in a binary $\mathrm{H}_{2} \mathrm{O}-\mathrm{CO}_{2}$ fluid] show that isothermal $\left(T \geq 540^{\circ} \mathrm{C}\right)$ infiltration of a fluid with $X\left(\mathrm{CO}_{2}\right) \geq 0.2$ results in complete antigorite dehydration, leaving an Ol-TI-Chl-carbonate. However, most veins are isochemical (Fig. 9). Therefore they must have formed by the second mechanism, without any significant influx of external fluids. Numerical studies (Connolly, 1997, 2010; Lasaga, 1989; Miller et al., 2003) have shown that a decrease in fluid pressure has the same kinetic effect on dehydration reactions as an increase in temperature. This conclusion is confirmed by experimental studies showing that serpentine and gypsum reaction rates are considerably enhanced by a reduction in the fluid pressure relative to the confining pressure (Rutter \& Brodie, 1988; Wang \& Wong, 2003; Llana-Fúñez et al., 2007, 2012; Arkwright et al., 2008; Rutter et al., 2009; Hildyard et al., 2011; Leclère et al., 2018).

Before the formation of the fractures the serpentinites may have been water-saturated, owing to the chemical and structural adjustment of antigorite under increasing temperature conditions. Wunder et al. (2001) experimentally showed that the antigorite polysome changes from 18 to 14 when temperature is increased from 450 to $650^{\circ} \mathrm{C}$ at $30 \mathrm{kbar}$. This change in polysomatism results in the release of up to $0.19 \mathrm{wt} \%$ of $\mathrm{H}_{2} \mathrm{O}$ (cf. Shen et al., 2020). Such a decrease of the antigorite 
polysome number with increasing metamorphic grade (from $m=17-18$ at $420 \pm 30^{\circ} \mathrm{C}$ to $m=14-18$ at $520 \pm 20^{\circ} \mathrm{C}$, at $3.5 \mathrm{kbar}$ ) has been documented in Alpe Zocca (Mellini et al., 1987). Yet water saturation is not a requirement for triggering the dehydration reactions below the equilibrium conditions.

Olivine-bearing veins in serpentinites are classically described as dehydration embrittlement veins (Nishiyama, 1989; Strating \& Vissers 1991; Healy et al., 2009; Dunkel et al., 2017). However, the systematic absence of talc or tremolite in the serpentinites hosting dehydration veins in the present study indicates that the fractures predate reactions (2) and (3). In consequence, they cannot have been produced by dehydration embrittlement phenomena associated with fluid overpressure owing to these reactions. They also cannot have formed by the channel-forming reactive porosity model proposed by Plümper et al. $(2017 \mathrm{~b})$ to account for the olivine-bearing veins in Erro-Tobio serpentinites (Ligurian Alps, Italy), as the characteristic hierarchical drainage structure, with a clear fluid-flow polarity direction (tree root-like arrangement), reported by Plümper et al. $(2017 b)$ is not observed in our study area, where unconnected parallel or conjugate-like arrangements of olivine-bearing veins are conspicuous (see Fig. 4a-c). A possible explanation for the dissimilarity between the two cases is the meter-scale chemical homogeneity of the reacting $\mathrm{Val}$ Malenco foliated antigoriteserpentinites, which contrasts with the small-scale compositional heterogeneity of the undeformed massive serpentinized peridotites in Erro-Tobbio (Scambelluri et al., 2001; Strating \& Vissers, 1991; Hermann et al., 2000; Plümper et al., 2017b). Indeed, the numerical model developed by Plümper et al. $(2017 b)$ to support the channel-forming reactive porosity mechanism is strongly dependent on the chemical heterogeneity of their input mid-ocean ridge serpentinized peridotite at all scales. We propose therefore that the fractures formed in response to an external process and that it is their effect on the pressure field that triggered the reaction. The remarkable common orientation of most veins at high angle to the isograds $\left(\sim N 70^{\circ}\right.$ nearly vertical, Fig. 2) suggests that they might have originated as extensional fractures associated with tangential extensional stresses produced in the host-rock by the Bergell intrusion (e.g. Koide \& Bhattacharji, 1975). It is worth noting that previous interpretations of the olivinebearing veins in the serpentinized peridotites of ErroTobbio also proposed a major role for external tectonic stresses in their formation (see fig. 3 of Strating \& Vissers, 1991).

The observed variability in the veins' morphology probably records different activity time lapses. A fluid pressure lower than lithostatic has to be maintained for the reaction to progress, but this situation is mechanically unstable. The porosity production and total volume change resulting from dehydration on the surface of the extensional crack walls might produce a transient fluidfilled porosity and transient permeability, but reaction progress will eventually be halted by mineral precipitation and unavoidable collapse of pores maintaining sub-lithostatic pressures. Very thin veins (Fig. 4a-c) probably record a pulse-like activity. In contrast, development of reaction fronts up to tens of centimeters wide requires that the vein worked as a high-permeability channel for a finite time, draining the fluids as the reaction progressed into the serpentinite host-rock (Figs $4 \mathrm{~d}$ and 5). The process allowing for the maintenance of these high-permeability channels under lithostatic pressures of c. $3.5 \mathrm{kbar}$ is not fully understood. However, all these veins have a well-developed core with a coarsegrained jackstraw olivine texture. The criss-cross arrangement of the stiff (at these low temperatures) olivine crystals may have played an essential role in avoiding full compaction of the vein for a given period of time.

Bucher (1998) presented a model based on a crackreaction-seal mechanism to account for olivine and tremolite veins replacing massive dolomite marble close to, or as enclaves in, the Bergell intrusion. These veins were generated during contact metamorphism in response to an important influx of metasomatizing $\mathrm{SiO}_{2}$-rich fluids, probably derived from the cooling intrusion. They are typically surrounded by symmetrical reaction zones that resemble those of the composite $\mathrm{Ol-Tlc}$ veins in this study (Figs $4 \mathrm{a}, \mathrm{d}$ and 5). These reaction zones show either straight (tremolite veins) or highly irregular (olivine veins) boundaries. This change in morphology was interpreted as the result of predominance of surface-controlled reaction kinetics over diffusive processes for straight reaction fronts, and the reverse for irregular fronts (Bucher, 1998). The crossover in time between the two mechanisms is temperature-dependent. This is consistent with the observation that $\mathrm{Ol}-( \pm \mathrm{Tr})$ veins, situated farther from Bergell intrusion contact display straight and sharp limits (Fig. 4a), whereas OI-Tlc veins are often composite (Figs $4 \mathrm{~d}$ and 5). Time scales for the propagation of the reaction fronts inferred by Bucher (1998), based on the observed thickness of reaction zones, are of several hundreds of years for the sharp tremolite veins formed at $450^{\circ} \mathrm{C}$ [similar to the $\mathrm{Ol}-( \pm \mathrm{Tr})$ veins studied here] and up to a thousand years for the diffuse olivine veins formed at $550^{\circ} \mathrm{C}$ (similar to the Ol-Tlc veins in our study area).

The morphology and size of olivine crystals in jackstraw-textured Ol-Tlc dehydration veins is rather outstanding given the low temperatures $\left(\leq 500^{\circ} \mathrm{C}\right)$ at which they were crystallized. This olivine texture has been repeatedly observed in metamorphic peridotites produced by dehydration reactions resulting in olivine associated with talc or enstatite (Matthes, 1971; Evans \& Trommsdorff, 1974a; Collerson et al., 1976; Hietanen, 1977; Snoke \& Calk, 1978; Nilsson, 1985; Bakke \& Korneliussen, 1986; Trommsdorff et al., 1998; Akinin, 1994; Padrón-Navarta et al., 2010a,b, 2011; Dilissen et al., 2018). This olivine morphology might reflect a particular growth kinetics linked to high effective fluid 
pressure in the dehydration veins. In unconstrained magmatic systems (free growth), feathery to hopper olivine crystal shapes are indeed known to result from fast growth in response to undercooling (Donaldson, 1976; Faure et al., 2003, 2006). Extrapolation of these results to fluid-mediated solid-state reactions is not obvious, but a possible explanation for development of similar textures in dehydrating ultramafic systems would be fast growth owing to an increase of the affinity of the reaction in response to effective fluid drainage in the veins. The coarse olivine grain size in veins (Figs $4 \mathrm{e}$ and $8 \mathrm{c}$ ) also suggests high time-integrated fluid-rock ratios. The marked change in grain size from the jackstraw-textured core of the composite veins to selvages (Fig. 5) may therefore record fluid focusing in the vein.

There is a marked resemblance between the olivine microstructure, SPO and CPO in the reaction zones associated with veins (Fig. 5) and in the pervasively dehydrated metaperidotite. Olivine crystals are systematically elongated parallel to [001] and flattened parallel to [010], marking the foliation, and intragranular misorientation is mainly accommodated by rotation around $<\mathrm{u} 0 \mathrm{w}>$ axes with dominance of [100] (compare Figs 5 and 13b). This suggests that the processes controlling olivine grain growth are similar and that viscous compaction was active in both domains.

The propagation of reaction zones generated by dehydration veins might lead to pervasive dehydration of serpentinites. Reminiscent of dehydrating veins included in the pervasive metaperidotite are relatively common. They have clear evidence of macroscopic deformation (but limited strain) suggesting that the formation of the veins predated the pervasive transformation of antigorite to the talc + olivine assemblage. However, it is unlikely that the entire pervasive metaperidotite domain formed by progression of the reaction zones associated with veins. The thickness of the reaction fronts in the composite veins, which does not exceed a few tens of centimeters, is consistent with slow propagation (velocities normal to the fracture orientation of the order of $5 \mathrm{~cm} \mathrm{ka}^{-1}$; Bucher 1998) and short vein lifetimes. The thermal model of Trommsdorff \& Connolly (1996) suggests that rocks at $890 \mathrm{~m}$ from the intrusion contact [a position intermediate between the isograds of reactions (2) and (3)] attained a maximum temperature of $520^{\circ} \mathrm{C}$ and began cooling c. $100 \mathrm{kyr}$ after the intrusion. Closer to the intrusion, maximum temperatures were higher and cooling slower. However, even under such conditions, the vein spacing should be of the order of $10 \mathrm{~m}$ or less to account for pervasive replacement of the serpentinites. Although it is difficult to map the veins in the pervasive metaperidotites, their spacing is significantly larger than this value.

Observations indicating auto-retrogression (rehydration) of the highest-grade assemblages in the pervasive domain close to the intrusion, in particular anthophyllite retrograded to talc (Trommsdorff \& Evans, 1972), imply that the time scale for fluid extraction in the pervasive domain was of the order of, or lower than, $100 \mathrm{kyr}$. These time scales are consistent with those predicted for viscous metamorphic compaction in numerical models (e.g. Connolly, 1997). If fluid production rates can be accommodated by viscous metamorphic compaction, the existence of highly permeable domains such as fractures does not perturb the generation of porosity waves that remain the main fluid extraction mechanism (see fig. 5 of Connolly, 2010).

\section{Olivine SPO and CPO: indicators of fluid flow?}

The jackstraw-textured veins, the associated reaction zones, and the pervasive metaperidotite show a strong correlation between olivine SPO and CPO. Olivine crystals are systematically elongated parallel to [001]. However, their orientation varies. In the veins, [001] $]_{\mathrm{OI}}$ axes are contained in the vein plane and [010] o axes are normal to it (Fig. 12), whereas in the veins' reaction zones and in the pervasive metaperidotite [001 $]_{\mathrm{Ol}}$ axes are contained in the foliation plane and $[010]_{\mathrm{Ol}}$ axes are normal to it (Figs 5 and 10). Because the orientation of the veins is usually at a high angle to the foliation (Fig. 2), the CPO and SPO in the veins are also often roughly normal to those in the reaction zones and pervasive metaperidotites. Within the jackstraw-textured domains, the olivine CPO is independent of the antigorite fabric in the reacting wall-rock (Fig. 12), whereas in the veins' reaction zones and in the pervasive metaperidotite there is a strong correlation between the olivine and antigorite CPO.

The olivine CPO in the pervasive metaperidotite has a strong correlation with the antigorite CPO. This relation may be produced by epitaxial growth of olivine on antigorite with the relation $[001]_{\mathrm{OI}}(010)_{\mathrm{OI}} \|[010]_{\mathrm{Atg}}$ $(001)_{\text {Atg }}$ which is one of the two orientation relations (No. 2) originally documented by transmission electron microscopy during olivine hydration to form antigorite (Boudier et al., 2010). The other orientation relation (No. 1), [001 $]_{\text {OI }}(100)_{\text {OIIII }}[010]_{\text {Atg }}(001)_{\text {Atg }}$, described by Boudier et al. (2010), is documented in some Ca-rich serpentinites, but not in the metaperidotites (Fig. 10). Orientation relations between coexisting antigorite and olivine have been recognized in olivine- and antigoritebearing serpentinites from the eastern part of $\mathrm{Val}$ Malenco, outside the contact metamorphism aureole [where olivine is formed by reactions (1a) and (1b) using EBSD data (Jung, 2009, 2011; Liu et al., 2018; Morales et al., 2018]. Liu et al. (2018) observed evidence for the relationship $(010)_{\mathrm{OI}} / /(001)_{\text {Atg }}$ (No. 2), which is the dominant one in our study area. Previous data for olivine from Jung $(2009,2011)$ for the same lithology outside the contact aureole show either [001 $]_{\mathrm{O}}$ or $[010]_{\mathrm{Ol}}$ at high angles to the foliation. However, the bulk fabric of the olivine in his study is rather oblique to the antigorite foliation, making it difficult to establish a clear crystallographic relationship. Morales et al. (2018) described the two antigorite-olivine topotaxy relations originally defined by Boudier et al. (2010) and two new 
ones, which are not observed in the present study. They observed, in particular, a strong concentration of [100] axes normal to the foliation caused by the orientation relationships $[001]_{O I}(100)_{O I} \mid l[010]_{\text {Atg }}(001)_{\text {Atg }}$ (No. 1) and $[100]_{O I}(010)_{\text {OIIII }}[001]_{\text {Atg }}(210)_{\text {Atg }}$ (No. 4). All these studies interpreted these orientation relations as resulting from the formation of antigorite at the expense of olivine. However, their studied samples come from the eastern part of Val Malenco, outside the contact metamorphism aureole, where prograde metamorphism of a previously serpentinized mantle section to upper greenschist or lower epidote amphibolite facies with no record of retrograde metamorphism is well documented (Trommsdorff \& Evans, 1974; Mellini et al., 1987; Peretti, 1988; Worden et al., 1991; Trommsdorff \& Connolly, 1996). Under these conditions, olivine formed at the expense of brucite and antigorite by reaction (1b). Indeed, olivine-antigorite crystallographic relations compatible with relation No. 2 (Boudier et al., 2010; Morales et al., 2018) have been reported from localities where prograde olivine is produced from reactions (1a) and (1b) (Nagasaki, Saganoseki and Toba areas in southest Japan; Soda \& Wenk, 2014). They were also documented in metaperidotites formed by reaction (3) (Happo antigorite-schists from central Japan; Nagaya et al., 2014), as in the present study, and by reaction (6) (Cerro del Almirez in Spain; Padrón-Navarta et al., 2015; Dilissen et al., 2018, Fig. 1b). All these rocks show bulk prograde olivine fabric with $[010]_{\text {ol }}$ oriented normal to the foliation, similar to the pervasive metaperidotites and reaction zones of the veins in our study area.

However, topotaxial growth cannot explain the olivine SPO and CPO in the jackstraw-textured veins. Olivine orientation in jackstraw textures is interpreted as resulting from oriented growth, with a preferred orientation of the fast-growing axis, which is [001] $]_{\mathrm{O}}$, along the fluid pressure gradient. The olivine SPO and $\mathrm{CPO}$ in the selvage of the composite vein in Fig. 5 might also be explained as produced by oriented growth, but with preferential flow of the fluid normal to the vein and parallel to the foliation of the host serpentinite, owing to an anisotropic permeability (see Kawano et al., 2011; Katayama et al., 2012). Oriented growth controlled by fluid flow in a medium with an anisotropic permeability may also have played a role in the formation of the olivine SPO and CPO in the metaperidotites. However, a contribution of topotaxial growth cannot be excluded in either the veins' reaction zones or the pervasive metaperidotites. Solid reorientation of the anisometric olivine crystals accommodated by the deformation of the weaker talc ( \pm chlorite) matrix during compaction may also have contributed to these SPOs and CPOs. In this case, the contrast in orientation between the foliation of the metaperidotites and the veins' trend (close to orthogonal; Fig. 2) could explain the change in the main rotation axis accommodating intracrystalline misorientations in olivine, which is [100] in the metaperidotites and [010] in deformed coarse-grained jackstrawtextured Ol-TIc veins (Fig. 13).

\section{Implications for dehydration reactions and fluid transport in subduction zones}

The jackstraw-textured dehydration veins described here were not produced by hydrofracturing (embrittlement owing to local increase in pore-fluid pressure). They were also not formed by coalescence of a fluidfilled microporosity produced by spatially heterogeneous triggering of the dehydration reactions. They were produced by external tectonic processes, which transiently and locally allowed for the dehydration reactions to occur at lower temperatures than the 'equilibrium' ones. These dehydration veins are well developed in Malenco probably as a result of the particular conditions at which the antigorite dehydration occurred: shallow depths and, hence, low lithostatic pressures ( $3.5 \mathrm{kbar}$ ), and anomalous thermal and stress fields related to the Bergell intrusion. Such veins are not, for instance, observed in Cerro del Almirez, where antigorite dehydration occurred at subduction-like conditions (Padrón-Navarta et al., 2011, Fig. 1b). This suggests that the veins in Val Malenco probably do not represent major features allowing for transport of antigorite dehydration fluids in subduction zones. However, these structures highlight the strong interplay between dehydration reaction kinetics (and by consequence fluid production rates) and deformation-induced variations in fluid pressure, which in a subduction environment may occur in response to hydrofracturing or to propagation of porosity waves. Such a coupling between enhanced fluid extraction rates by hydrofracturing and antigorite dehydration kinetics was, for instance, proposed based on the variations in texture of the metaperidotites in Cerro del Almirez (Padrón-Navarta et al., 2010b, 2011).

Prograde olivine in Malenco has weak to moderate but clear SPO and CPO, indicating that even if dehydration occurs under static conditions, it might contribute to seismic anisotropy in the mantle wedge. However, the present results imply that the interpretation of this seismic anisotropy is not straightforward. First, the data in the veins show that the olivine CPO is not controlled by the pre-existing antigorite $\mathrm{CPO}$, but that it may result from anisotropic growth in the presence of fluid pressure gradients and, hence, record fluid flow patterns. An important role of fluid flow in the formation of fabrics in prograde metaperidotites has also been inferred in Cerro del Almirez, where an increase in elongation and change in orientation of the magnetite aggregates from the serpentinites to the metaperidotites, and a correlation between the magnetite lineation and the orientation of $[001]_{\mathrm{Ol}}$ in the metaperidotites, were documented (Dilissen et al., 2018). These observations open a new path for mapping fluid flow in subduction zones.

Moreover, even if topotaxial growth plays a role in the formation of olivine CPO, the relation between the antigorite CPO and the deformation reference frame is not always clear. Fast S-wave polarization normal to the flow direction is observed only if $[100]_{O I}$ is 
concentrated normal to the flow direction. This orientation may be produced by the topotactic relation [001] $]_{\mathrm{O}}$ $(100)_{\text {OIII }}[010]_{\text {Atg }}(001)_{\text {Atg }}$, which is not observed in the Malenco pervasive metaperidotites. It might also be produced by the topotactic relation $[001]_{\mathrm{OI}}(010)_{\mathrm{O}}$ $\|[010]_{\text {Atg }}(001)_{A t g}$, if the $[010]_{\text {Atg }}$ was aligned in the flow direction before the pervasive dehydration. Based on the assumption that the $[010]_{\text {Atg }}$ axes correspond to the macroscopic lineation in the serpentinites (and therefore shear direction), some researchers have classified the resulting prograde olivine fabric as B-type (Jung, 2011; Nagaya et al., 2014; Liu et al., 2018; but see Morales et al., 2018). However, most often both [100] $]_{\text {Atg }}$ and $[010]_{\text {Atg }}$ are dispersed in a girdle in the foliation plane of the serpentinites, with no strong point maximum of [010] $]_{\text {Atg }}$ (Fig. 10; Padrón-Navarta et al., 2012; Soda \& Wenk, 2014; Kern et al., 2015; Dilissen et al., 2018). Furthermore, when SPO data for magnetite are available (Dilissen et al., 2018) there is no clear correlation between the concentrations of $[100]_{\text {Atg }}$ or $[010]_{\text {Atg }}$ and the lineation defined by magnetite aggregates.

\section{CONCLUSIONS}

Macro- to microstructures observed in the Malenco unit in proximity to the Bergell contact aureole record two different modes of fluid extraction during dehydration reactions. Dehydration veins allowed transient, rapidly focused, fluid flow as the result of a crack-reaction-seal mechanism, allowing for dehydration to occur locally at temperatures lower than the equilibrium conditions. This resulted in fast anisotropic olivine grain growth under high time-integrated fluid-rock ratios, leading to the development of jackstraw textures, characterized by a criss-cross arrangement of prismatic olivine crystals elongated parallel to the [001] direction. The olivine [001] axis and $(010)_{\mathrm{O}}$ plane tend to be systematically oriented within the vein plane. In addition, some veins developed reaction zones propagating outwards from the initial crack. In these reaction zones, olivine crystals are oriented with $[001]_{\mathrm{O}}$ dominantly normal to the vein and $[010]_{O}$ normal to the foliation in the serpentinite wall-rock. Both observations suggest oriented growth of olivine controlled by fluid pressure gradients, with orientation of the fast growth direction [001 $]_{\mathrm{OI}}$ along the maximum fluid pressure gradient.

However, it is unlikely that fluid extraction by the veins played a significant role in the pervasive dehydration of serpentinites observed within $c .770 \mathrm{~m}$ of the contact with the Bergell intrusion, for the following reasons: (1) this transformation is characterized by a wide reaction front of c. $150 \mathrm{~m}$, composed of partially reacted rocks, where the intensity of the reaction bears no clear spatial relation to dehydration veins; (2) full transformation of the serpentinites in metaperidotites by progression of reaction zones around veins would imply a decimeter-scale spacing of veins, which is not observed in the field. We interpret therefore the foliated metaperidotites as formed at near equilibrium conditions, with extraction of the fluids produced by viscous metamorphic compaction. Evidence for limited solid-state deformation of the metaperidotites after their crystallization includes undulose extinction in olivine crystals that preserve nevertheless their prismatic shapes and delicate fingering contacts with talc, and bent talc and chlorite crystals. The SPO and CPO of olivine in the pervasive metaperidotites and in the reaction zones around the veins could be inherited from the $\mathrm{CPO}$ of antigorite in the serpentinite, via epitaxial or topotaxial growth, or be controlled by fluid flow with a higher permeability parallel to the foliation. The present results suggest that metamorphic olivine SPO and CPO may represent potential markers of fluid flow direction during dehydration reactions.

\section{ACKNOWLEDGEMENTS}

We thank A. Lewerentz and three anonymous reviewers for their constructive (and in some cases very detailed) reviews, and late A. Lumsden for editorial management. We are grateful to F. Barou for technical assistance in the EBSD-SEM CNRS-INSU national facility at Géosciences Montpellier. We acknowledge J. Hermann, R. Lafay, L. Labrousse, C. J. Garrido and V. López Sánchez-Vizcaíno for constructive discussions, and L. Mameri for unconditional field support. C. Nevado and D. Delmas supplied high-quality polished thin sections for EBSD measurements. We warmly thank F. Lenatti and his family for their hospitality and logistics during the field campaign.

\section{FUNDING}

This work has been funded by the Institut National des Sciences de I'Univers (INSU), Centre National de la Recherche Scientifique (CNRS), program TelluS/ SYSTER, project MinCompact (AO2016-1030192/ AO2017-996352) and Agence National de la Recherche (ANR), through the project ANR-16-TERC-0013-01. M.C. has benefited from a PhD scholarship from the University of Montpellier.

\section{SUPPLEMENTARY DATA}

Supplementary data are available at Journal of Petrology online.

\section{REFERENCES}

Ague, J. J. (2011). Extreme channelization of fluid and the problem of element mobility during Barrovian metamorphism. American Mineralogist 96, 333-352.

Akinin, V. (1994). Metaultramafics of the crystalline basement of the Chukchi Peninsula. In: Simakov, K. V. and Thurston, D. $\mathrm{K}$. (eds) Proceedings of the International Conference on Arctic Margins. Magadan, Russia: Russian Academy of Sciences Far East Branch, Northeast Science Center, pp. 214-219. 
Arkwright, J. C., Rutter, E. H., Brodie, K. H. \& Llana-Fúnez, S. (2008). Role of porosity and dehydration reaction on the deformation of hot-pressed serpentinite aggregates. Journal of the Geological Society, London 165, 639-649.

Bachmann, F., Hielscher, R., Jupp, P. E., Pantleon, W., Schaeben, H. \& Wegert, E. (2010). Inferential statistics of electron backscatter diffraction data from within individual crystalline grains. Journal of Applied Crystallography 43, 1338-1355.

Bakke, S. \& Korneliussen, A. (1986). Jack-straw-textured olivines in some Norwegian metaperidotites. Norsk Geologisk Tidsskrift 66, 271-276.

Bedford, J., Fusseis, F., Leclère, H., Wheeler, J. \& Faulkner, D. (2017). A 4D view on the evolution of metamorphic dehydration reactions. Scientific Reports 7, 6881.

Beinlich, A., Klemd, R., John, T. \& Gao, J. (2010). Trace-element mobilization during Ca-metasomatism along a major fluid conduit: eclogitization of blueschist as a consequence of fluid-rock interaction. Geochimica et Cosmochimica Acta 74, 1892-1922.

Boudier, F., Baronnet, A. \& Mainprice, D. (2010). Serpentine mineral replacements of natural olivine and their seismic implications: oceanic lizardite versus subduction-related antigorite. Journal of Petrology 51, 495-512.

Bruton, C. J. \& Helgeson, H. C. (1983). Calculation on the chemical and thermodynamic consequences of differences between fluid and geostatic pressure in hydrothermal system. American Journal of Science 283-A, 540-588.

Bucher, K. (1998). Growth mechanisms of metasomatic reaction veins in dolomite marbles from the Bergell Alps. Mineralogy and Petrology 63, 151-171.

Bunge, H. J. (1982). Chapter 4 - Expansion of orientation distribution functions in series of generalized spherical harmonics: Three-dimensional textures. In: Bunge, H. J. (ed.) Texture Analysis in Materials Science. Oxford, UK: Butterworth-Heinemann, pp. 47-118.

Capitani, G. \& Mellini, M. (2004). The modulated crystal structure of antigorite: The $m=17$ polysome. American Mineralogist 89, 147-158.

Capitani, G. C. \& Mellini, M. (2006). The crystal structure of a second antigorite polysome $(m=16)$, by single-crystal synchrotron diffraction. American Mineralogist 91, 394-399.

Clément, M., Padrón-Navarta, J. A., Tommasi, A. \& Mainprice, D. (2018). Non-hydrostatic stress field orientation inferred from orthopyroxene (Pbca) to low-clinoenstatite (P21/c) inversion in partially dehydrated serpentinites. American Mineralogist 103, 993-1001.

Collerson, K. D., Jesseau, C. W. \& Bridgwater, D. (1976). Contrasting types of bladed olivine in ultramafic rocks from the Archaean of Labrador. Canadian Journal of Earth Sciences 13, 442-450.

Connolly, J. A. D. (1997). Devolatilization-generated fluid pressure and deformation-propagated fluid flow during prograde regional metamorphism. Journal of Geophysical Research 102, 149-173.

Connolly, J. A. D. (2009). The geodynamic equation of state: What and how. Geochemistry, Geophysics, Geosystems 10, Q10014.

Connolly, J. A. D. (2010). The mechanics of metamorphic fluid expulsion. Elements 6, 165-172.

Connolly, J. A. D. \& Podladchikov, Y. (1998). Compaction-driven fluid flow in viscoelastic rock. Geodinamica Acta 11, 55-84.

Connolly, J. A. D. \& Podladchikov, Y. Y. (2013). A hydromechanical model for lower crustal fluid flow. In: Harlov, D. E. \& Austrheim, H. (eds) Metasomatism and the Chemical
Transformation of Rock. Lecture Notes in Earth System Sciences. Berlin: Springer, pp. 599-658.

Connolly, J. A. D. \& Podladchikov, Y. Y. (2015). An analytical solution for solitary porosity waves: dynamic permeability and fluidization of nonlinear viscous and viscoplastic rock. Geofluids 15, 269-292.

Connolly, J. A. D. \& Trommsdorff, V. (1991). Petrogenetic grids for metacarbonate rocks: pressure-temperature phase-diagram projection for mixed-volatile systems. Contributions to Mineralogy and Petrology 108, 93-105.

Coombs, D. S. (1993). Dehydration veins in diagenetic and very-low-grade metamorphic rocks: features of the crustal seismogenic zone and their significance to mineral facies. Journal of Metamorphic Geology 11, 389-399.

Coombs, D. S., Ellis, A. J., Fyfe, W. S. \& Taylor, A. M. (1959). The zeolite facies, with comments on the interpretation of hydrothermal syntheses. Geochimica et Cosmochimica Acta 17, 53-107.

Dahlen, F. A. (1992). Metamorphism of nonhydrostatically stressed rocks. American Journal of Science 292, 184-198.

Demouchy, S., Tommasi, A., Boffa Ballaran, T. \& Cordier, P. (2013). Low strength of Earth's uppermost mantle inferred from tri-axial deformation experiments on dry olivine crystals. Physics of the Earth and Planetary Interiors 220, 37-49.

Demouchy, S., Mussi, A., Barou, F., Tommasi, A. \& Cordier, P. (2014). Viscoplasticity of polycrystalline olivine experimentally deformed at high pressure and $900^{\circ} \mathrm{C}$. Tectonophysics 623, 123-135.

Dilissen, N., Hidas, K., Garrido, C. J., Kahl, W.-A., López Sánchez-Vizcaíno, V. \& Padrón-Navarta, J. A. (2018). Textural evolution during high-pressure dehydration of serpentinite to peridotite and its relation to stress orientations and kinematics of subducting slabs: Insights from the Almirez ultramafic massif. Lithos 320-321, 470-489.

Donaldson, C. H. (1976). An experimental investigation of olivine morphology. Contributions to Mineralogy and Petrology 57, 187-213.

Dunkel, K. G., Austrheim, H., Ildefonse, B. \& Jamtveit, B. (2017). Transfer of olivine crystallographic orientation through a cycle of serpentinisation and dehydration. Contributions to Mineralogy and Petrology 172, 64.

Etheridge, M. A., Wall, V. J. \& Vernon, R. H. (1983). The role of the fluid phase during regional metamorphism and deformation. Journal of Metamorphic Geology 1, 205-226.

Etschmann, B., Brugger, J., Pearce, M. A., Ta, C., Brautigan, D., Jung, M. \& Pring, A. (2014). Grain boundaries as microreactors during reactive fluid flow: experimental dolomitization of a calcite marble. Contributions to Mineralogy and Petrology 168, 1-12.

Evans, B. W. (2004). The serpentinite multisystem revisited: Chrysotile is metastable. International Geology Review 46, 479-506.

Evans, B. W. \& Trommsdorff, V. (1970). Regional metamorphism of ultramafic rocks in the Central Alps: parageneses in the system $\mathrm{CaO}-\mathrm{MgO}-\mathrm{SiO}_{2}-\mathrm{H}_{2} \mathrm{O}$. Schweizerische Mineralogische und Petrographische Mitteilungen 50, 481-492.

Evans, B. W. \& Trommsdorff, V. (1974a). On elongate olivine of metamorphic origin. Geology 2, 131-132.

Evans, B. W. \& Trommsdorff, V. (1974b). Stability of enstatite + talc, and $\mathrm{CO}_{2}$-metasomatism of metaperidotite, Val d'Efra, Lepontine Alps. American Journal of Science 274, 274-296.

Faure, F., Trolliard, G., Nicollet, C. \& Montel, J. M. (2003). A developmental model of olivine morphology as a function of the cooling rate and the degree of undercooling. Contributions to Mineralogy and Petrology 145, 251-263.

Faure, F., Arndt, N. \& Libourel, G. (2006). Formation of spinifex texture in komatiites: an experimental study. Journal of Petrology 47, 1591-1610. 
Flekkøy, E. G., Malthe-Sorenssen, A. \& Jamtveit, B. (2002). Modeling hydrofracture. Journal of Geophysical Research 107, 1-11.

Frost, R. (1975). Contact metamorphism of serpentinite, chloritic blackwall and rodingite at Paddy-Go-Easy Pass, Central Cascades, Washington. Journal of Petrology 16, 272-313.

Fyfe, W. S., Turner, F. J. \& Verhoogen, J. (1958). Metamorphic Reactions and Metamorphic Facies. Geological Society of America, Memoirs 73, 259 pp.

Greenwood, H. J. (1961). The system $\mathrm{NaAISi}_{2} \mathrm{O}_{6}-\mathrm{H}_{2} \mathrm{O}$-argon: total pressure and water pressure in metamorphism. Journal of Geophysical Research 66, 3923-3946.

Healy, D., Reddy, S. M., Timms, N. E., Gray, E. M. \& Vitale Brovarone, A. (2009). Trench-parallel fast axes of seismic anisotropy due to fluid-filled cracks in subducting slabs. Earth and Planetary Science Letters 283, 75-86.

Hermann, J. (1997). The Braccia gabbro (Malenco, Alps): Permian intrusion at the crust to mantle interface and Jurassic exhumation during rifting. PhD thesis, ETH Zurich, No. 12102, 194 pp.

Hermann, J. \& Muntener, O. (1996). Extension-related structures in the Malenco-Margna-system: Implications for paleogeography and consequences for rifting and Alpine tectonics. Schweizerische Mineralogische und Petrographische Mitteilungen 76, 501-519.

Hermann, J., Müntener, O., Trommsdorff, V., Hansmann, W. \& Piccardo, G. B. (1997). Fossil crust-to-mantle transition, Val Malenco (Italian Alps). Journal of Geophysical Research: Solid Earth 102, 20123-20132.

Hermann, J., Müntener, O. \& Scambelluri, M. (2000). The importance of serpentinite mylonites for subduction and exhumation of oceanic crust. Tectonophysics 327, 225-238.

Hielscher, R. \& Schaeben, H. (2008). A novel pole figure inversion method: specification of the MTEX algorithm. Journal of Applied Crystallography 41, 1024-1037.

Hietanen, A. (1977). Blades of olivine in ultramafic rocks from Northern Sierra Nevada, California. Journal of Research, US Geological Survey 5, 217-219.

Hildyard, R. C., Llana-fúnez, S., Wheeler, J., Faulkner, D. R. \& Prior, D. J. (2011). Electron backscatter diffraction (EBSD) analysis of bassanite transformation textures and crystal structure produced from experimentally deformed and dehydrated gypsum. Journal of Petrology 52, 839-856.

Holland, T. J. B. \& Powell, R. (2011). An improved and extended internally consistent thermodynamic dataset for phases of petrological interest, involving a new equation of state for solids. Journal of Metamorphic Geology 29, 333-383.

Hyndman, R. D. \& Peacock, S. M. (2003). Serpentinization of the forearc mantle. Earth and Planetary Science Letters 212, 417-432.

Idrissi, H., Bollinger, C., Boioli, F., Schryvers, D. \& Cordier, P. (2016). Low-temperature plasticity of olivine revisited with in situ TEM nanomechanical testing. Science Advances 2, e1501671.

John, T., Gussone, N., Podladchikov, Y. Y., Bebout, G. E., Dohmen, R., Halama, R., Klemd, R., Magna, T. \& Seitz, H.-M. (2012). Volcanic arcs fed by rapid pulsed fluid flow through subducting slabs. Nature Geoscience 5, 489.

Jung, H. (2009). Deformation fabrics of olivine in Val Malenco peridotite found in Italy and implications for the seismic anisotropy in the upper mantle. Lithos 109, 341-349.

Jung, H. (2011). Seismic anisotropy produced by serpentine in mantle wedge. Earth and Planetary Science Letters 307, 535-543.

Kahl, W.-A., Dilissen, N., Hidas, K., Garrido, C. J., LópezSánchez-Vizcaíno, V. \& Román-Alpiste, M. J. (2017). 3-D microstructure of olivine in complex geological materials reconstructed by correlative X-ray $\mu$-CT and EBSD analyses. Journal of Microscopy 268, 193-207.

Kar, A., McEldrew, M., Stout, R. F., Mays, B. E., Khair, A., Velegol, D. \& Gorski, C. A. (2016). Self-generated electrokinetic fluid flows during pseudomorphic mineral replacement reactions. Langmuir 32, 5233-5240.

Katayama, I., Terada, T., Okazaki, K. \& Tanikawa, W. (2012). Episodic tremor and slow slip potentially linked to permeability contrasts at the Moho. Nature Geoscience 5, 731-734.

Kawano, S., Katayama, I. \& Okazaki, K. (2011). Permeability anisotropy of serpentinite and fluid pathways in a subduction zone. Geology 39, 939-942.

Kern, H., Lokajicek, T., Svitek, T. \& Wenk, H.-R. (2015). Seismic anisotropy of serpentinite from Val Malenco, Italy. Journal of Geophysical Research: Solid Earth 120, 4113-4129.

Koide, H. \& Bhattacharji, S. (1975). Formation of fractures around magmatic intrusion and their role in ore localization. Economic Geology 70, 781-799.

Lafay, R., Baumgartner, L. P., Putlitz, B. \& Siron, G. (2019). Oxygen isotope disequilibrium during serpentinite dehydration. Terra Nova 31, 94-101.

Lasaga, A. C. (1989). Fluid flow and chemical reaction kinetics in metamorphic systems: a new simple model. Earth and Planetary Science Letters 94, 417-424.

Leclère, H., Faulkner, D., Llana-fúnez, S., Bedford, J. \& Wheeler, J. (2018). Reaction fronts, permeability and fluid pressure development during dehydration reactions. Earth and Planetary Science Letters 496, 1-24.

Liu, W., Zhang, J. \& Barou, F. (2018). B-type olivine fabric induced by low temperature dissolution creep during serpentinization and deformation in mantle wedge. Tectonophysics 722, 1-10.

Llana-Fúñez, S., Brodie, K. H., Rutter, E. H. \& Arkwright, J. C. (2007). Experimental dehydration kinetics of serpentinite using pore volumometry. Journal of Metamorphic Geology 25, 423-438.

Llana-Fúnez, S., Wheeler, J. \& Faulkner, D. R. (2012). Metamorphic reaction rate controlled by fluid pressure not confining pressure: implications of dehydration experiments with gypsum. Contributions to Mineralogy and Petrology 164, 69-79.

López Sánchez-Vizcaíno, V., Trommsdorff, V., Gómez-Pugnaire, M. T., Garrido, C. J., Müntener, O. \& Connolly, J. A. D. (2005). Petrology of titanian clinohumite and olivine at the high-pressure breakdown of antigorite serpentinite to chlorite harzburgite (Almirez Massif, S. Spain). Contributions to Mineralogy and Petrology 149, 627-646.

Mackwell, S. J., Kohlstedt, D. L. \& Paterson, M. S. (1985). The role of water in the deformation of olivine single crystals. Journal of Geophysical Research 90, 11319-11333.

Mainprice, D., Bachmann, F., Hielscher, R. \& Schaeben, H. (2014). Descriptive tools for the analysis of texture projects with large datasets using MTEX: strength, symmetry and components. In: Faulkner, D. R., Mariani, E. and Mecklenburgh, J. (eds) Rock Deformation from Field, Experiments and Theory: A Volume in Honour of Ernie Rutter. Geological Society, London, Special Publications, 409, 251-271.

Malvoisin, B., Podladchikov, Y. Y. \& Vrijmoed, J. C. (2015). Coupling changes in densities and porosity to fluid pressure variations in reactive porous fluid flow: Local thermodynamic equilibrium. Geochemistry, Geophysics, Geosystems 16, 4362.

Manning, C. E. \& Ingebritsen, S. E. (1999). Permeability of the continental crust: implications of geothermal data and metamorphic systems. Reviews of Geophysics 37, 127-150.

Matthes, S. (1971). Die ultramafischen Hornfelse, insbesondere ihre Phasenpetrologie. Fortschritte der Mineralogie 48, 109-127. 
Mellini, M., Trommsdorff, V. \& Compagnoni, R. (1987). Antigorite polysomatism: behaviour during progressive metamorphism. Contributions to Mineralogy and Petrology 97, 147-155.

Miller, S. A., van der Zee, W., Olgaard, D. L. \& Connolly, J. A. D. (2003). A fluid-pressure feedback model of dehydration reactions: experiments, modelling, and application to subduction zones. Tectonophysics 370, 241-251.

Montrasio, A. \& Trommsdorff, V. (1983). Guida all'escursione del Massiccio di Val Masino-Bregaglia, Val Malenco Occidentale, Sondrio. (Chiareggio, 16-18 luglio 1983). Memorie della Società Geologica Italiana 26, 421-434.

Morales, L. F. G., Mainprice, D. \& Kern, H. (2018). Olivine-antigorite orientation relationships: Microstructures, phase boundary misorientations and the effect of cracks in the seismic properties of serpentinites. Tectonophysics 724-725, 93-115.

Müntener, O. (1997). The Malenco peridotites (Alps): petrology and geochemistry of subcontinental mantle and Jurassic exhumation during rifting. PhD thesis, ETH Zurich, No. 12103, $205 \mathrm{pp}$.

Müntener, O. \& Hermann, J. (1996). The Val Malenco lower crust-upper mantle complex and its field relations (Italian Alps). Schweizerische Mineralogische und Petrographische Mitteilungen 76, 475-500.

Müntener, O., Hermann, J. \& Trommsdorff, V. (1999). Cooling history and exhumation of lower-crustal granulite and upper mantle (Malenco, Eastern Central Alps). Journal of Petrology 41, 175-200.

Nagaya, T., Wallis, S. R., Kobayashi, H., Michibayashi, K., Mizukami, T., Seto, Y., Miyake, A. \& Matsumoto, M. (2014). Dehydration breakdown of antigorite and the formation of B-type olivine CPO. Earth and Planetary Science Letters 387, 67-76.

Nakashima, Y. (1995). Transport model of buoyant metamorphic fluid by hydrofracturing in leaky rock. Journal of Metamorphic Geology 13, 727-736.

Nilsson, G. (1985). Nickel-copper deposits in Sweden. In: Papunen, H. and Gorbunov, G. I. (eds) Nickel-Copper Deposits of the Baltic Shield and Scandinavian Caledonides. Geological Survey of Finland, Bulletin 333, 313-362.

Nishiyama, T. (1989). Kinetics of hydrofracturing and metamorphic veining. Geology 17, 1068-1071.

Okamoto, A., Shimizu, H., Fukuda, J., Muto, J. \& Okudaira, T. (2017). Reaction-induced grain boundary cracking and anisotropic fluid flow during prograde devolatilization reactions within subduction zones. Contributions to Mineralogy and Petrology 172, 1-23.

Padrón-Navarta, J. A., Hermann, J., Garrido, C. J., López Sánchez-Vizcaíno, V. \& Gómez-Pugnaire, M. T. (2010a). An experimental investigation of antigorite dehydration in natural silica-enriched serpentinite. Contributions to Mineralogy and Petrology 159, 25-42.

Padrón-Navarta, J. A., Tommasi, A., Garrido, C. J., SánchezVizcaíno, V. L., Gómez-Pugnaire, M. T., Jabaloy, A. \& Vauchez, A. (2010b). Fluid transfer into the wedge controlled by high-pressure hydrofracturing in the cold top-slab mantle. Earth and Planetary Science Letters 297, 271-286.

Padrón-Navarta, J. A., Sánchez-Vizcaí, V. L., Garrido, C. J. \& Gómez-Pugnaire, M. T. (2011). Metamorphic record of high-pressure dehydration of antigorite serpentinite to chlorite harzburgite in a subduction setting (Cerro del Almirez, Nevado-Filábride complex, Southern Spain). Journal of Petrology 52, 2047-2078.

Padrón-Navarta, J. A., Sánchez-Vizcaíno, V. L., Hermann, J., Connolly, J. A D., Garrido, C. J., Gómez-Pugnaire, M. T. \& Marchesi, C. (2013). Tschermak's substitution in antigorite and consequences for phase relations and water liberation in high-grade serpentinites. Lithos 178, 186-196.

Padrón-Navarta, J. A., Tommasi, A., Garrido, C. J. \& López Sánchez-Vizcaíno, V. (2012). Plastic deformation and development of antigorite crystal preferred orientation in high-pressure serpentinites. Earth and Planetary Science Letters 349-350, 75-86.

Padrón-Navarta, J. A., Tommasi, A., Garrido, C. J. \& Mainprice, D. (2015). On topotaxy and compaction during antigorite and chlorite dehydration: an experimental and natural study. Contributions to Mineralogy and Petrology 169, 1-20.

Peretti, A. (1988). Occurrence and stabilities of opaque minerals in the Malenco Serpentinite (Sondrio, Italy). PhD thesis, Swiss Federal Institute of Technology, Zurich, Switzerland, No. 8740.

Peretti, A., Dubessy, J., Mullis, J., Frost, B. R. \& Trommsdorff, V. (1992). Highly reducing conditions during Alpine metamorphism of the Malenco peridotite (Sondrio, northern Italy) indicated by mineral paragenesis and $\mathrm{H}_{2}$ in fluid inclusions. Contributions to Mineralogy and Petrology 112, 329-340.

Pfeifer, H. R., Biino, G., Ménot, R. P. \& Stille, P. (1993). Ultramafic rocks in the pre-Mesozoic basement of the Central and External Western Alps. In: von Raumer, J. F. and Neubauer, F. (eds) Pre-Mesozoic Geology in the Alps. Berlin: Springer, pp. 119-143.

Plümper, O., Botan, A., Los, C., Liu, Y., Malthe-Sørenssen, A. \& Jamtveit, B. (2017a). Fluid-driven metamorphism of the continental crust governed by nanoscale fluid flow. Nature Geoscience 10, 685.

Plümper, O., John, T., Podladchikov, Y. Y., Vrijmoed, J. C. \& Scambelluri, M. (2017b). Fluid escape from subduction zones controlled by channel-forming reactive porosity. Nature Geoscience 10, 150-156.

Putnis, A. (2002). Mineral replacement reactions: from macroscopic observations to microscopic mechanisms. Mineralogical Magazine 66, 689-708.

Putnis, A. \& John, T. (2010). Replacement processes in the Earth's crust. Elements 6, 159-164.

Putnis, A. \& Putnis, C. V. (2007). The mechanism of reequilibration of solids in the presence of a fluid phase. Journal of Solid State Chemistry 180, 1783-1786.

Raleigh, C. B. (1968). Mechanisms of plastic deformation of olivine. Journal of Geophysical Research 73, 5391-5406.

Rutter, E. H. \& Brodie, K. H. (1988). Experimental 'sytectonic' dehydration of serpentinite under conditions of controlled pore water pressure. Journal of Geophysical Research: Solid Earth 93, 4907-4932.

Rutter, E. H., Llana-Fúnez, S. \& Brodie, K. H. (2009). Dehydration and deformation of intact cylinders of serpentinite. Journal of Structural Geology 31, 29-43.

Scambelluri, M., Rampone, E. \& Piccardo, G. B. (2001). Fluid and element cycling in subducted serpentinite: a trace-element study of the Erro-Tobbio high-pressure ultramafites (Western Alps, NW Italy). Journal of Petrology 42, 55-67.

Shen, T., Zhang, C., Chen, J., Hermann, J., Zhang, L., PadrónNavarta, J. A., Chen, L., Xu, J. \& Yang, J. (2020). Changes of antigorite cell parameters close to the antigorite dehydration reaction at subduction zone conditions. American Mineralogist, in press, doi: 10.2138/am-2020-7159.

Shive, P. N., Frost, B. R. \& Peretti, A. (1988). The magnetic properties of metaperidotitic rocks as a function of metamorphic grade: implications for crustal magnetic anomalies. Journal of Geophysical Research 93, 12187-12195.

Snoke, A. W. \& Calk, L. C. (1978). Jackstraw-textured talc-olivine rocks, Preston Peak area, Klamath Mountains, 
California. Geological Society of America Bulletin 89, 223-230.

Soda, Y. \& Wenk, H.-R. (2014). Antigorite crystallographic preferred orientations in serpentinites from Japan. Tectonophysics 615-616, 199-212.

Strating, E. H. H. \& Vissers, R. L. M. (1991). Dehydration-induced fracturing of eclogite-facies peridotites: Implications for the mechanical behaviour of subducting oceanic lithosphere. Tectonophysics 200, 187-198.

Taetz, S., John, T., Bröcker, M. \& Spandler, C. (2016). Fluid-rock interaction and evolution of a high-pressure/lowtemperature vein system in eclogite from New Caledonia: insights into intraslab fluid flow processes. Contributions to Mineralogy and Petrology 171, 90.

Taetz, S., John, T., Bröcker, M., Spandler, C. \& Stracke, A. (2018). Fast intraslab fluid-flow events linked to pulses of high pore fluid pressure at the subducted plate interface. Earth and Planetary Science Letters 482, 33-43.

Torres-Roldán, R. L., García-Casco, A. \& García-Sánchez, P. A. (2000). CSpace: an integrated workplace for the graphical and algebraic analysis of phase assemblages on 32-bit Wintel platforms. Computers and Geosciences 26, 779-793.

Trommsdorff, V. (1970). Mineral parageneses in magnesian rocks of the progressive metamorphic series of the central Alps. Naturwissenschaften 57, 304-305.

Trommsdorff, V. (1983). Metamorphose magnesiumreicher Gesteine: Kritischer Vergleich von Natur, Experiments und thermodynamischer Datenbasis. Fortschritte der Mineralogie 61, 283-308.

Trommsdorff, V. \& Nievergel, T.-P. (1983). The Bregaglia (Bergell)-lorio intrusive and its field relations. Memorie della Società Geologica Italiana 26, 55-68.

Trommsdorff, V. \& Connolly, J. A. D. (1996). The ultramafic contact aureole about the Bregaglia (Bergell) tonalite: Isograds and a thermal model. Schweizerische Mineralogische und Petrographische Mitteilungen 76, 537-547.

Trommsdorff, V. \& Evans, B. W. (1972). Progressive metamorphism of antigorite schist in the Bergell tonalite aureole (Italy). American Journal of Science 272, 423-437.

Trommsdorff, V. \& Evans, B. (1974). Alpine metamorphism of peridotitic rocks. Schweizerische Mineralogische und Petrographische Mitteilungen 72, 229-242.
Trommsdorff, V. \& Evans, B. W. (1977). Antigorite-ophicarbonates: Contact metamorphism in Valmalenco, Italy. Contributions to Mineralogy and Petrology 62, 301-312.

Trommsdorff, V. \& Evans, B. W. (1980). Titanian hydroxyl-clinohumite: Formation and breakdown in antigorite rocks (Malenco, Italy). Contributions to Mineralogy and Petrology 72, 229-242.

Trommsdorff, V., López Sánchez-Vizcaíno, V., Gómez-Pugnaire, M. T. \& Müntener, O. (1998). High pressure breakdown of antigorite to spinifex-textured olivine and orthopyroxene, SE Spain. Contributions to Mineralogy and Petrology 132, 139-148.

Trommsdorff, V., Hermann, J., Muntener, O., Pfiffner, M. \& Risold, A. C. (2000). Geodynamic cycles of subcontinental lithosphere in the Central Alps and the Arami enigma. Journal of Geodynamics 30, 77-92.

Trommsdorff, V., Montrasio, A., Hermann, J., Müntener, O., Spillmann, P. \& Gieré, R. (2005). The geological map of Valmalenco. Schweizerische Mineralogische und Petrographische Mitteilungen 85, 1-13.

Vollmer, F. W. (1990). An application of eigenvalue methods to structural domain analysis. Geological Society of America Bulletin 102, 786-791.

Von Blanckenburg, F., Früh-Green, G., Diethelm, K. \& Stille, P. (1992). Nd-, Sr-, O-isotopic and chemical evidence for a two-stage contamination history of mantle magma in the Central-Alpine Bergell intrusion. Contributions to Mineralogy and Petrology 110, 33-45.

Wang, W. H. \& Wong, T. F. (2003). Effects of reaction kinetics and fluid drainage on the development of pore pressure excess in a dehydrating system. Tectonophysics 370, 227-239.

Whitney, D. L. \& Evans, B. W. (2010). Abbreviations for names of rock-forming minerals. American Mineralogist 95, 185-187.

Worden, R. H., Droop, G. T. R. \& Champness, P. E. (1991). The Reaction Antigorite $\rightarrow$ Olivine + Talc $+\mathrm{H}_{2} \mathrm{O}$ in the Bergell Aureole. Mineralogical Magazine 55, 367-377.

Wunder, B., Wirth, R. \& Gottschalk, M. (2001). Antigorite: Pressure and temperature dependence of polysomatism and water content. European Journal of Mineralogy 13, 485-495. 